\title{
Nerve growth factor: from the early discoveries to the potential clinical use
}

\author{
Luigi Aloe ${ }^{1}$, Maria Luisa Rocco ${ }^{1}$, Patrizia Bianchi ${ }^{1}$ and Luigi Manni ${ }^{2 *}$
}

\begin{abstract}
The physiological role of the neurotrophin nerve growth factor (NGF) has been characterized, since its discovery in the 1950s, first in the sensory and autonomic nervous system, then in central nervous, endocrine and immune systems. NGF plays its trophic role both during development and in adulthood, ensuring the maintenance of phenotypic and functional characteristic of several populations of neurons as well as immune cells. From a translational standpoint, the action of NGF on cholinergic neurons of the basal forebrain and on sensory neurons in dorsal root ganglia first gained researcher's attention, in view of possible clinical use in Alzheimer's disease patients and in peripheral neuropathies respectively. The translational and clinical research on NGF have, since then, enlarged the spectrum of diseases that could benefit from NGF treatment, at the same time highlighting possible limitations in the use of the neurotrophin as a drug. In this review we give a comprehensive account for almost all of the clinical trials attempted until now by using NGF. A perspective on future development for translational research on NGF is also discussed, in view of recent proposals for innovative delivery strategies and/or for additional pathologies to be treated, such as ocular and skin diseases, gliomas, traumatic brain injuries, vascular and immune diseases.
\end{abstract}

Keywords: Nerve growth factor, Alzheimer's disease, Parkinson's disease, Peripheral neuropathies, Skin ulcers, Neurotrophic keratitis, Glaucoma, Hypoxic-ischemic brain injury, Optic glioma

\section{Nerve growth factor}

Nerve growth factor (NGF) is the first discovered member of the neurotrophin family [1]. NGF is essential for the development and phenotypic maintenance of neurons in the peripheral nervous system (PNS) and for the functional integrity of cholinergic neurons in the central nervous system (CNS) (Figure 1) [2]. The amino acid and messenger RNA sequences of this neurotrophin have been classified and indicate that NGF is a highly conserved molecule that shares considerable homology within different species [3]. The mature, active form of NGF descend from proteolitic cleavage of a precursor form (ProNGF), that have important roles during development and in adult life, having both pro-apoptotic and neurotrophic properties $[4,5]$.

NGF exerts its biological action by challenging the specific receptor tropomyosin kinase receptor A (TrkA),

\footnotetext{
* Correspondence: luigi.manni@ift.cnr.it

${ }^{2}$ Institute of Translational Pharmacology, National Research Council (CNR), via Fosso del Cavaliere 100, 00136, Rome, Italy

Full list of author information is available at the end of the article
}

which is a typical tyrosine kinase receptor [6]. The major cytosolic/endosomal pathways activated by the TrkA are Ras-mitogen activated protein kinase (MAPK), extracellular signal-regulated kinase (ERK), phosphatidylinositol 3-kinase (PI3K) -Akt, and Phospholipase C (PLC) $-\gamma$ [7-9]. NGF also binds to and activate the low-affinity, non-selective p75 pan-neurotrophin receptor $\left(\mathrm{p} 75^{\mathrm{NTR}}\right)$. This receptor is a transmembrane glycoprotein that regulates signaling through TrkA [9-11]; binding of NGF to $\mathrm{p} 75^{\mathrm{NTR}}$ activates additional signaling pathways that, in the absence of co-expressed TrkA, may signal a cell to die via apoptosis [10-12]. Signaling pathways activated by $\mathrm{p} 75^{\mathrm{NTR}}$ are the Jun kinase signaling cascade, NF-kB and ceramide generation [13].

The discovery of NGF dated the '50s of the last century and was awarded with the Nobel prize in 1986 [13]. In 1953, Rita Levi-Montalcini, working in the Victor Hamburger laboratory at Washington University (Saint Louis, MA, USA), grafted a piece of mouse sarcoma tissue onto chick embryos whose wing buds had been

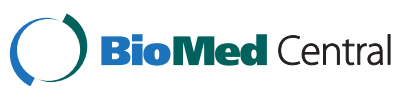



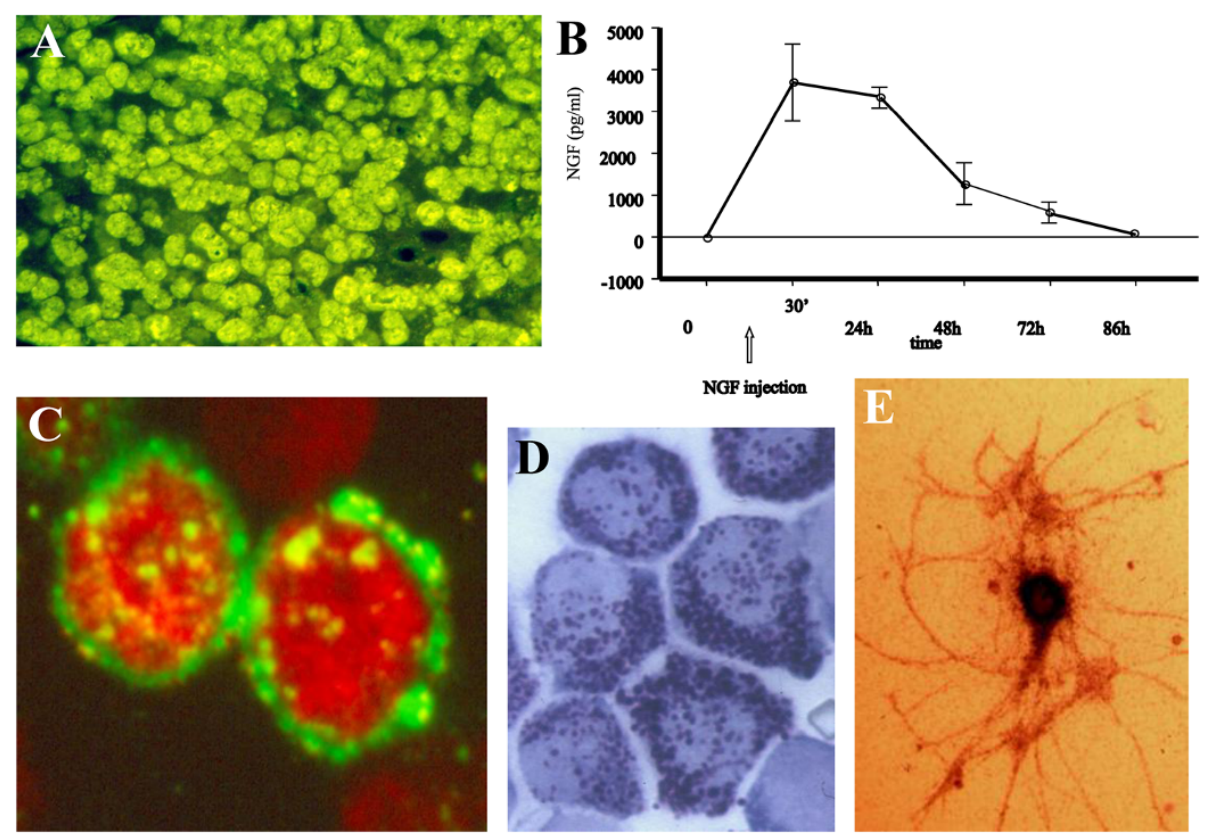

Figure 1 NGF is produced by every peripheral tissue/organ that is innervated by sensory afferents and/or sympathetic efferents, as well as by central and peripheral nervous system and immune cells. The largest amount of the neurotrophin is produced in mice submaxillary glands, as revealed by immunofluorescence staining depicted in panel $\mathbf{A}$, that are the source for murine NGF used in several clinical trials. When intravenously injected in rats (B), NGF levels quickly increases in the bloodstream, reaching a peak within 30 min and remaining above baseline levels up until $72 \mathrm{~h}$. Peripheral NGF injection induces peculiar effects on immune circulating cells, such as the overexpression of its receptor TrkA on circulating lymphocytes $(\mathbf{C})$ or degranulation of peritoneal mast cells (D). Radiolabelled, intra-cerebroventricular injected NGF is captured by TrkA-expressing neurons, such as cholinergic neurons in the basal forebrain complex (E).

extirpated. She discovered that the tumor tissue produced a soluble factor that promoted the growth of nearby sensory and sympathetic ganglia [13]. Collaborating with the biochemist Stanley Cohen, they isolated the substance responsible and named it NGF. For over 35 years, NGF has been considered as a very powerful and selective growth factor for sympathetic and sensory neurons and for cells derived from the neuronal crest (Figure 2) [14-16]. In these neurons, NGF dynamically controls neurotransmitters and neuropeptides synthesis. In sympathetic neurons the production of norepinephrine is regulated by NGF through selective induction of tyrosine hydroxylase (TH) [17]. In the dorsal root ganglion (DRG) the expression of neuropeptides such as Substance P (SP) and Calcitonin Gene-Related Peptide (CGRP) by primary sensory neurons is under NGF control [18] and in vivo deprivation of NGF, as a result of nerve transection or anti-NGF treatment, causes a marked decrease in SP and CGRP synthesis [19]. NGF supply from the innervation field influences the neuronal plasticity that allows the adult nervous system to modify its structure and functions in response to stimuli. Indeed, the constitutive synthesis of NGF in adult tissues correlates with PNS neurons phenotypic features, such as innervation density, cell body size, axonal terminal sprouting, dendrites arborization, induction or inhibition of neuropeptides and neurotransmitters or transmitterproducing enzymes [17-21].

In the central nervous system (CNS), the greatest amount of NGF is produced in the cortex, the hippocampus and in the pituitary gland; although significant quantities of this neurotrophin are also produced in other areas, including the basal ganglia, thalamus, spinal cord and in the retina [22]. The NGF plays a pivotal role in the survival and function of cholinergic neurons of the basal forebrain complex (BFC) (Figures 1 and 2) [23], such functions include attention, arousal, motivation, memory and consciousness. Since BFC neurons are highly affected in Alzheimer's disease (AD), NGF has been indicated as a potential protective and/or curative factor for neurodegenerative disorders associated with these neurons [24]. In the CNS, NGF also regulates phenotypic features in noradrenergic nuclei of hypothalamus and brainstem, participating in the central regulation of autonomic response and in the modulation of stress axis activity [25-29].

Cells of the immune-hematopoietic system also produce and utilize NGF $[2,30,31]$. Since the early description of the effects of NGF on mast cells (Figures 1 and 2) $[32,33]$, the role played by the neurotrophin in the regulation of immune functions and immune cells' behavior has been greatly characterized. NGF receptors are 


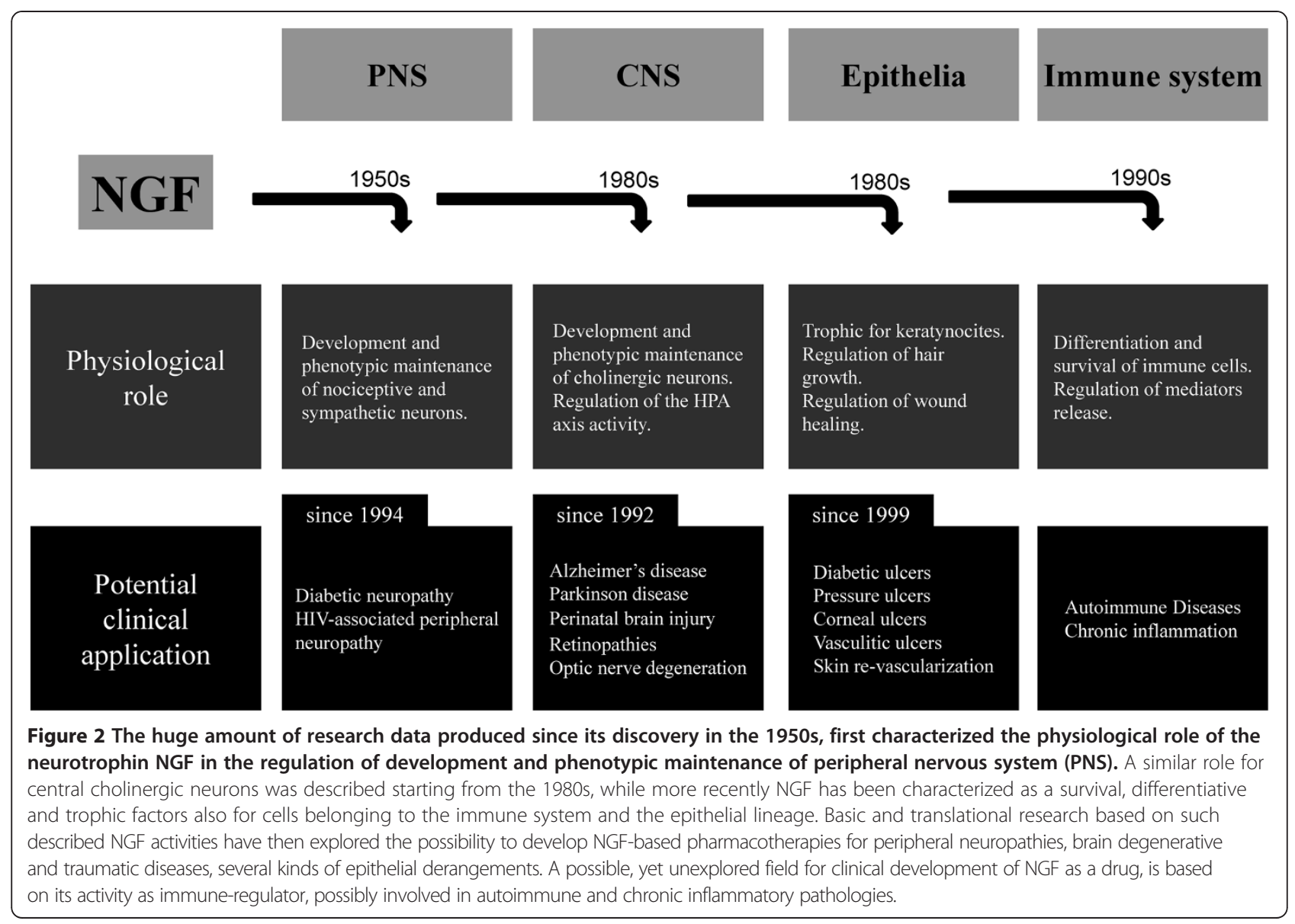

expressed in immune organs and on immune cell populations (Figure 1) allowing NGF to modulate cell differentiation and regulate the immune response. NGF affects the survival and/or differentiation and/or phenotypic features of hematopoietic stem cells [34-37], granulocytes [38-46], lymphocytes [47-54] and monocytes [47,54-59]. NGF concentrations in the tissues change during inflammation and inflammatory mediators induce NGF synthesis in a variety of cell types [60-62]. Enhanced production of NGF has been reported in inflamed tissues of patients with inflammatory and autoimmune diseases [60,61,63], but the reasons why NGF concentration is enhanced and how this can affect inflammatory responses are far from being fully understood.

\section{Clinical use of NGF}

\section{Peripheral neuropathies}

According to the classical neurotrophic model, NGF is produced in and released by target tissues, is then captured by specific receptors expressed on nerve terminals and retrogradely transported to the neuron body, where it exerts its neurotrophic activity $[64,65]$. Any perturbation in the neurotrophic circuit could generate peripheral nerve dysfunction and neuronal sufferance, as those characterizing peripheral neuropathies. Data obtained in animal models and in human pathologies demonstrated that disease-associated peripheral neuropathies could be associated with either deregulation of NGF synthesis, transport and utilization by PNS neurons [66-71]. This gives to NGF an etiological value in the development of neuropathic symptoms associated with, i.e., diabetes, HIV infections or chemotherapy, and point to the neurotrophin as a possible pharmacological tool in the treatment of peripheral neuropathies (see Table 1 for a comprehensive summary of clinical trials on NGF in peripheral neuropathies).

\section{Diabetes}

Diabetes is often characterized by major complications such as dysfunction and degeneration of several types of PNS neurons/fibers [72,73]. Sensory involvement is predominant, the small diameter sensory fiber degeneration being responsible for the more debilitating symptoms. Deficits of NGF transport $[66,67,74]$, serum and tissue content $[66,67,75,76]$ have been demonstrated in experimental diabetes. Major components of the NGF signaling pathway have been also found deregulated in experimental diabetes [77-79], as well as the production of neuromodulators that 
Table 1 Summary of clinical trials with NGF on peripheral neuropathies

\begin{tabular}{|c|c|c|c|c|c|c|}
\hline Disease & Study type & $\begin{array}{l}\text { NGF type and } \\
\text { dosage }\end{array}$ & $\begin{array}{l}\text { Delivery } \\
\text { route }\end{array}$ & Outcome & Side effects & References \\
\hline $\begin{array}{l}\text { Healthy } \\
\text { subjects }\end{array}$ & $\begin{array}{l}\text { Phase I double-masked, } \\
\text { randomized, placebo- } \\
\text { controlled study. }\end{array}$ & $\begin{array}{l}\text { Recombinant human } \\
\text { NGF. Doses ranging } \\
\text { from } 0.03 \text { to } 1 \mu \mathrm{g} / \mathrm{kg} \text {. }\end{array}$ & $\begin{array}{l}\text { Subcutaneous, } \\
\text { intravenous. }\end{array}$ & \multicolumn{2}{|c|}{$\begin{array}{l}\text { The study evaluated the safety of single doses } \\
\text { of rhNGF in healthy human volunteers. No } \\
\text { life-threatening adverse events were seen at } \\
\text { any dose. Dose-dependent mild to moderate } \\
\text { muscle pain and hyperalgesia at the injection } \\
\text { site was reported. }\end{array}$} & {$[84,85]$} \\
\hline \multirow[t]{2}{*}{$\begin{array}{l}\text { Diabetic } \\
\text { polyneuropathy }\end{array}$} & $\begin{array}{l}\text { Phase II, placebo-controlled } \\
\text { clinical trial. }\end{array}$ & $\begin{array}{l}\text { Recombinant human } \\
\text { NGF. } 0.1 \text { and } 0.3 \mu \mathrm{g} / \\
\mathrm{kg} .\end{array}$ & Subcutaneous. & $\begin{array}{l}\text { Significant improvement of } \\
\text { neuropathic symptoms } \\
\text { after } 6 \text { months of } \\
\text { treatment. }\end{array}$ & $\begin{array}{l}\text { Dose-dependent } \\
\text { hyperalgesia at } \\
\text { the injection site. }\end{array}$ & {$[86,87]$} \\
\hline & $\begin{array}{l}\text { Phase III, randomized, } \\
\text { double-blind, placebo- } \\
\text { controlled clinical trial. }\end{array}$ & $\begin{array}{l}\text { Recombinant human } \\
\text { NGF. } 0.1 \mu \mathrm{g} / \mathrm{kg} \text {. }\end{array}$ & Subcutaneous. & $\begin{array}{l}\text { Not significant compared } \\
\text { to placebo. }\end{array}$ & $\begin{array}{l}\text { Dose-dependent } \\
\text { hyperalgesia at } \\
\text { the injection site. }\end{array}$ & {$[87,88]$} \\
\hline \multirow[t]{2}{*}{$\begin{array}{l}\text { HIV-associated } \\
\text { peripheral } \\
\text { neuropathy }\end{array}$} & $\begin{array}{l}\text { Phase II, multicenter, placebo- } \\
\text { controlled, randomized } \\
\text { clinical trial. }\end{array}$ & $\begin{array}{l}\text { Recombinant human } \\
\text { NGF. } 0.1 \text { and } 0.3 \mu \mathrm{g} / \\
\mathrm{kg} \text {. }\end{array}$ & Subcutaneous. & $\begin{array}{l}\text { Significant improvements } \\
\text { in daily and global pain } \\
\text { assessments. }\end{array}$ & $\begin{array}{l}\text { Injection site } \\
\text { pain. Severe } \\
\text { transient myalgic } \\
\text { pain. }\end{array}$ & {$[92,93]$} \\
\hline & $\begin{array}{l}\text { Long term (48 weeks) phase } \\
\text { II, multicenter, placebo- } \\
\text { controlled, randomized } \\
\text { clinical trial. }\end{array}$ & $\begin{array}{l}\text { Recombinant human } \\
\text { NGF. } 0.1 \text { and } 0.3 \mu \mathrm{g} / \\
\mathrm{kg} .\end{array}$ & Subcutaneous. & $\begin{array}{l}\text { No improvement in } \\
\text { neuropathy severity. }\end{array}$ & $\begin{array}{l}\text { Injection site } \\
\text { pain. }\end{array}$ & [94] \\
\hline
\end{tabular}

is known to be under NGF control [80,81]. On the other hand NGF supply in animal models of diabetic neuropathies reverses neuropathic signs, by protecting the affected PNS neurons and normalizing their activity $[82,83]$.

The production of recombinant human NGF (rhNGF) has been first developed and tested in phase I clinical trial, where moderate side effects, such as myalgias and injection site hyperalgesia, were evidenced in healthy subjects $[84,85]$. A phase II clinical trial on 250 patients affected by diabetic polyneuropathy was then performed $[86,87]$. The study revealed a significant improvement of neuropathic symptoms in the NGF-treated patients, but also evidenced the occurrence of side effects, such as injection site hyperalgesia, myalgias and arthralgias, that limited the blinding of the study [86,87]. The results of the study were, however, considered encouraging and clinical trial continued in a phase III study [88]. Those enrolled 1019 patients who were treated subcutaneously with rhNGF, 3 times a week for 48 weeks. The study revealed almost the same side effects of the previous ones, but failed to demonstrate substantial benefits from the NGF treatment. The relative failure of the study, compared to previous phase II trial, was attributed to the low dosage, limited by the occurrence of side effects, but other causes, as the characteristic of patient population, choice of end points, measurement of neuropathy and the possible low quality of the rhNGF used, were not excluded [87].

\section{Human immunodeficiency virus}

Peripheral nerve complications in human immunodeficiency virus (HIV) patients could arise from the virus itself or from the anti-viral drugs [89-91]. A phase II, multicenter, placebo-controlled, randomized clinical trial with subcutaneous rhNGF on 270 HIV-infected patients affected by sensory neuropathy has been performed a decade ago [92,93]. A significant positive effect of rhNGF was found on neuropathic pain, with injection site pain as the most frequent side effect. It was concluded that rhNGF was safe and well tolerated. In contrast with the latter study, the same group published a report on the long-term (48 weeks) effect of rhNGF in an open-label study of 200 subjects with HIV-associated distal sensory neuropathy [94]. While apparently safe and well tolerated, the NGF did not improve the severity of neuropathy, measured by neurological examination, quantitative sensory testing and epidermal nerve fiber density.

\section{Other peripheral neuropathies that could benefit from NGF treatment}

In vitro and in vivo studies provided support for clinical trials on rhNGF in chemotherapy-induced peripheral neurotoxicity (CIPN). The development of sensory neuropathies often limits the dosage and time-extension of anti-tumor therapies based on cytotoxic agents [90,95]. NGF has been demonstrated to counteract the reduction of neurite outgrowth from rat DRG in vitro, induced by cisplatin, vincristine or Taxol [96] and the development of behavioral manifestations of cisplatin-induced neuropathy [69,97-101]. Moreover, a positive correlation was found between the decrease of circulating NGF and the severity of CIPN in humans [102]. 
A decrease in NGF has been also reported in leprosyaffected human skin and nerve $[103,104]$. The NGF produced by keratinocytes has been found decreased in skin biopsies from leprosy patients [103]. Moreover, a significant loss of intra-epidermal innervation [105], and a lowered expression of sensory neuromodulators that are under NGF control, such as Substance P [104] and the sodium channel SNS/PN3 [103], have been found in leprosy-affected skin. From a clinical standpoint all these NGF system alterations found in leprosy skin correlated with the characteristic sensory deficit and the loss of skin neurotrophism that might lead to trophic ulcers and mutilation [106].

\section{CNS diseases}

Studies on rodents and primates have demonstrated that exogenous NGF was able at neuro-protecting BFC neurons by both traumatic insults and age-related cholinergic decline [107-111]. It has also been demonstrated that NGF could directly act on two classical hallmark of $\mathrm{AD}$ : $\beta$-amyloid neurotoxicity and tau hyperphosphorylation. Indeed in vitro and in vivo experiments indicated NGF

Table 2 Summary of clinical trials with NGF on central nervous system's diseases

\begin{tabular}{|c|c|c|c|c|c|c|}
\hline Disease & Study type & NGF type and dosage & $\begin{array}{l}\text { Delivery } \\
\text { route }\end{array}$ & Outcome & Side effects & References \\
\hline \multirow[t]{5}{*}{$\begin{array}{l}\text { Alzheimer's } \\
\text { Disease }\end{array}$} & Single case report. & $\begin{array}{l}\text { Mouse NGF. } 75 \mu \mathrm{g} / \text { day for three } \\
\text { months, total amount: } 6.6 \mathrm{mg} \text {. }\end{array}$ & ICV. & $\begin{array}{l}\text { Increase of cortical blood flow } \\
\text { and brain nicotine uptake. } \\
\text { Improvement of verbal episodic } \\
\text { memory. }\end{array}$ & Weight loss. & [119] \\
\hline & $\begin{array}{l}\text { Three patients case } \\
\text { report. }\end{array}$ & $\begin{array}{l}\text { Mouse NGF. Two patients: } 75 \mu \mathrm{g} / \text { day } \\
\text { or three months, total amount: } \\
6.6 \mathrm{mg} \text {. One patient: } 16 \mu \mathrm{g} / \text { day for } \\
2 \text { weeks and } 3.4 \mu \mathrm{g} / \text { day for further } \\
10 \text { weeks, total amount: } 0.55 \mathrm{mg} \text {. }\end{array}$ & ICV. & Increase of brain nicotine uptake. & $\begin{array}{l}\text { Weight loss. } \\
\text { Back pain. }\end{array}$ & [120] \\
\hline & Phase I clinical trial. & $\begin{array}{l}\text { Human NGF genetically } \\
\text { engineered into autologous } \\
\text { grafted fibroblasts. }\end{array}$ & $\begin{array}{l}\text { Gene } \\
\text { therapy. }\end{array}$ & $\begin{array}{l}\text { Improvement in the rate of } \\
\text { cognitive decline. Significant } \\
\text { increases in cortical 18- } \\
\text { fluorodeoxyglucose after } \\
\text { treatment, as revealed by PET } \\
\text { scans. }\end{array}$ & $\begin{array}{l}\text { Absence of } \\
\text { long-term } \\
\text { adverse } \\
\text { effect in } 6 \\
\text { out of } 8 \\
\text { patients. }\end{array}$ & [182] \\
\hline & $\begin{array}{l}\text { Phase I randomized, } \\
\text { controlled dose- } \\
\text { escalating study to } \\
\text { assess the safety and } \\
\text { tolerability of CERE- } 110 \text {. }\end{array}$ & $\begin{array}{l}\text { Human NGF genetically } \\
\text { engineered into adeno- } \\
\text { associated virus vector (CERE- } \\
\text { 110). }\end{array}$ & $\begin{array}{l}\text { Gene } \\
\text { therapy. }\end{array}$ & Ongoing. & Ongoing. & [183-185] \\
\hline & $\begin{array}{l}\text { Open label, } 12 \text { month } \\
\text { study on } 6 \text { patients. }\end{array}$ & $\begin{array}{l}\text { Human NGF genetically } \\
\text { engineered in human retinal cells } \\
\text { encapsulated in implantable } \\
\text { device }\end{array}$ & $\begin{array}{l}\text { Gene } \\
\text { therapy. }\end{array}$ & $\begin{array}{l}\text { The phase I trial was a safety and } \\
\text { tolerability study. The } \\
\text { implantation and removal of } \\
\text { device were safe and well } \\
\text { tolerated. Positive neurological } \\
\text { outcomes were also found in } 2 \\
\text { out of } 6 \text { patients. }\end{array}$ & $\begin{array}{l}\text { No NGF- } \\
\text { related } \\
\text { adverse } \\
\text { events were } \\
\text { found. }\end{array}$ & {$[187,190]$} \\
\hline $\begin{array}{l}\text { Parkinson's } \\
\text { disease }\end{array}$ & Single case report. & $\begin{array}{l}\text { Mouse NGF. } 3.3 \mathrm{mg} \text { infused via } \\
\text { implanted cannula over } 23 \text { days, } \\
\text { as support for adrenal medulla } \\
\text { graft. }\end{array}$ & $\begin{array}{l}\text { Intra- } \\
\text { putaminal. }\end{array}$ & $\begin{array}{l}\text { NGF treatment could prolong } \\
\text { the effect of adrenal chromaffin } \\
\text { grafts in human PD. }\end{array}$ & Not reported. & [121] \\
\hline \multirow{2}{*}{$\begin{array}{l}\text { Optic } \\
\text { glioma and } \\
\text { advanced } \\
\text { optic nerve } \\
\text { atrophy. }\end{array}$} & $\begin{array}{l}\text { Five patients case } \\
\text { study. }\end{array}$ & $\begin{array}{l}\text { Mouse NGF. } 1 \mathrm{mg} \text { total over } \\
10 \text { days in daily applications. }\end{array}$ & $\begin{array}{l}\text { Topical } \\
\text { (eye). }\end{array}$ & $\begin{array}{l}\text { Improvement in visual evoked } \\
\text { potentials (VEP). }\end{array}$ & Not reported. & {$[206]$} \\
\hline & $\begin{array}{l}\text { Single patient case } \\
\text { study. }\end{array}$ & $\begin{array}{l}\text { Mouse NGF. } 1 \mathrm{mg} \text { total over } \\
10 \text { days in daily applications. }\end{array}$ & $\begin{array}{l}\text { Topical } \\
\text { (eye). }\end{array}$ & $\begin{array}{l}\text { Reversible improvements of } \\
\text { visual function and } \\
\text { electrophysiological } \\
\text { measurements. }\end{array}$ & Not reported. & {$[207]$} \\
\hline \multirow[t]{2}{*}{$\begin{array}{l}\text { Hypoxic- } \\
\text { ischemic } \\
\text { perinatal } \\
\text { brain injury }\end{array}$} & $\begin{array}{l}\text { Two patients case } \\
\text { study. }\end{array}$ & $\begin{array}{l}\text { Mouse NGF. } 0.1 \text { mg/day for } \\
10 \text { days. }\end{array}$ & ICV. & $\begin{array}{l}\text { Improvement in the comatose } \\
\text { status, increased alpha/theta ratio } \\
\text { in the EEG, reduction of malacic } \\
\text { areas and improvement, in right } \\
\text { temporal and occipital cortices } \\
\text { perfusion. }\end{array}$ & Not reported. & [123] \\
\hline & $\begin{array}{l}\text { Two patients case } \\
\text { study. }\end{array}$ & $\begin{array}{l}\text { Mouse NGF. } 0.1 \text { mg/day for } \\
10 \text { days. }\end{array}$ & ICV. & $\begin{array}{l}\text { Improvement in EEG and SPECT } \\
\text { parameters. An increase of } \\
\text { doublecortin in CSF. }\end{array}$ & Not reported. & [122] \\
\hline
\end{tabular}


as a direct anti-amyloidogenic factor, being able to regulate both amyloid gene expression and protein processing [112-114]. Furthermore NGF has been shown to counteract tau hyperphosphorylation both in vitro [115] and in vivo [116]. Further studies on human tissues failed to demonstrate a reduction of NGF production in the cortex and hippocampus of $\mathrm{AD}$ patients, while the evidence for a decreased NGF immunoreactivity in the BFC suggested that impaired NGF supply via retrograde transport could be the effective cause of cholinergic neurodegeneration in $\mathrm{AD}$ [117]. Thus, the correct therapeutic strategy should pursue NGF deliverance in the proximity of cholinergic cell bodies, where the effective NGF deficits have been revealed, rather than in axon terminal regions (i.e. cortex and hippocampus).

The greatest challenge in the delivery of NGF to CNS resides in its inability in crossing the blood-brain barrier (BBB), when systemically administered [118]. For this reason, the intra-cerebro-ventricular (ICV) way of NGF delivery has been pursued in AD patients in two separate clinical trials (see Table 2 for a summary of NGF clinical trials in CNS disease). In the first study, a single patient was treated with murine NGF (mNGF) infusion into the right ventricle [119]. The treatment resulted in a marked transient increase in uptake and binding of $\left[{ }^{11} \mathrm{C}\right]$-nicotine in the frontal and temporal cortex, a persistent increase in cortical blood flow and a progressive decrease of slow wave EEG activity Tests of verbal episodic memory were also improved whereas other cognitive tests were not. As relevant side effect, weight loss was reported [119]. The results of a second study on ICV mNGF delivery was published in 1998 [120]. The relative positive outcomes found in the first study were confirmed in the two patients treated with higher doses of mNGF. However, the major finding of the study could be considered the occurrence of important and severely limiting side effects: reversible weight loss during the mNGF infusion period and, most importantly, development of back pain symptoms after the beginning of ICV infusion that most probably reflects the NGF-mediated hyper-activation of nociceptive transmission system in the spinal cord. These side effects were considered to outweigh the positive outcomes and lead to discontinuation of ICV infusion-based trials in AD patients.

The ICV NGF infusion has been also pursued in single or small groups of patients in diseases such as Parkinson's disease (PD) [121] and hypoxic-ischemic perinatal brain injury [122-124]. The rationale for the use of NGF infusion in PD is linked to its supportive role for adrenal medullary cells engrafted in the basal ganglia of PD patients $[125,126]$. The cell replacement therapy for PD patients by autologous chromaffin adrenal tissue grafting into the caudate nucleus was pursued in the 1980's $[127,128]$, and based on previous positive indications coming from animal studies on models of PD $[129,130]$. Overall, these studies lead to consensus over the lack of long-lasting effects, due to lack of specific support to engrafted cells. NGF ICV infusion was then attempted, in light of NGF effects on survival, neurite outgrowth, and functionality of grafts of adrenal chromaffin cells to the basal ganglia. The study [121] reports the case of a 63 year-old patient that underwent autologous graft of adrenal medulla into the putamen, supported by a 23 day ICV infusion of mNGF. During the 13 months follow up the patient had a rapid decrease in rigidity and hyperkinesias that was similar to what observed in previous studies on autologous graft of chromaffin tissue in PD patients. The specific effect of mNGF support to the graft was identified in a slower improvement of motor functions that was extended for 11 months after the graft procedure. Thus NGF treatment could prolong the effect of adrenal chromaffin grafts in human PD [121].

As for the clinical studies performed on children with traumatic brain injury (TBI), the rationale for NGF utilization comes from animal studies, showing that NGF can reduce neurological deficits following brain injury in animals [131], and from the observation that NGF levels in the cerebro-spinal fluid (CSF) of TBI patients have a positive correlation with neurological outcomes [124]. Two studies were attempted with an ICV infusion of mNGF in children with TBI. In the first study [123] two infants aged 8 and 9 months were treated with mNGF infused into the right cerebral ventricle for 10 days starting 30 days after the hypoxic-ischemic brain injury. Very preliminary observations detected an improvement in the comatose status, increased alpha/ theta ratio in the EEG, reduction of malacic areas and improvement, in one child only, of the regional cerebral perfusion in right temporal and occipital cortices, as measured by SPECT. A second study [122] in 2 infants aged 8 and 13 months and affected by hypoxic-ischemic brain damage, showed the results of mNGF ICV infusion, starting 4 months after TBI. Again, an improvement in EEG and SPECT parameters was scored with a concomitant increase of doublecortin, a protein expressed by newly formed neurons, in the CSF. These studies, tough limited by a small number of patients, indicated a possible effect of NGF in the treatment of TBI secondary to hypoxic-ischemic brain insult, but did not investigate potential side effects linked to the ICV infusion.

\section{Skin ulcers}

Beside its action as a neurotrophic factor for nerve cells, NGF has been characterized as a regulatory factor for many non-neuronal cell types, expressing NGF receptors [2]. The role of NGF on skin biology is particularly relevant from a clinical perspective. Production and 
utilization of NGF has been demonstrated in skin cells, as keratinocytes [132-134], and in immune cells that are resident or recruited in epidermal tissue following trauma or inflammation [135-137]. NGF deregulation has been described in diseased skin [137-143]. The effects of NGF on the healthy and diseased skin could be directly exerted via NGF receptors expressed on epidermal and dermal cells, or by NGF influence on PNS skin innervation that is known to regulate skin homeostasis by neuropeptides and neurotransmitter release [144-152]. The possible role of NGF as a therapeutic in skin trauma and/or diseases was investigated in animal models of wound healing [62,140,152,153]. Later on, topical application of NGF has been pursued in several forms of epithelial derangements and skin disease (summarized in Table 3).

Topical mNGF has been applied in three diabetic patients affected by on foot ulcers [154]. The treatment induced a local progressive restoration of nerve function and an almost complete relapse of ulcers within 514 weeks since the beginning of treatment.

Another clinical study was performed in patients affected by chronic vasculitic ulcers secondary to rheumatoid arthritis (RA) or systemic sclerosis (SSc) [155]. The leg ulcers of the patients with rheumatoid arthritis $(n=4)$ showed a rapid reduction in volume which led, in all cases, to heal within 5-8 weeks. Descriptive variables such as pain, presence of granulation, absence of inflammation also improved in the same period. SSc patients $(n=4)$ were treated on both the hand and leg ulcers. Despite little improvement in inflammatory states and ulcer size, none of the ulcers reached healing after 8 weeks. The authors speculated over the different effects in RA and SSc ulcers as attributable to disease features diversity, especially in the microvascular fibrosis that characterizes SSc and could reduce NGF access to damaged cells [155].
Pressure ulcers have been also treated with topical mNGF and results reported in two separate studies from the same group $[156,157]$. The first study described a single patient affected by pressure ulcers bilaterally located on the elbows [156]. The right elbow was treated with mNGF and the ulcer was reduced by $1 / 3$ while the left elbow ulcer was substantially unchanged. In the second report, a randomized, double-blind, placebocontrolled trial was described, aimed at investigating the effects of topical treatment with mNGF in patients with severe, non-infected pressure ulcers of the foot [157]. Topical mNGF was applied to 18 patients, while another 18 patients received vehicle treatment only. The average reduction in pressure ulcer area after 6-week follow-up period was statistically significantly greater in the treatment group than in the control group.

Another interesting case report investigated the effect of topical NGF treatment in ischemic skin revascularization [158]. In this case the described effects of NGF as a promoter of vascular-endothelial growth factor (VEGF) and neo-vascularization [159] gave the rationale background for treatment of a child with a severe crush syndrome of the lower left limb with subcutaneous mNGF. The gradual improvement of the ischemic treated area was observed throughout the treatment period, with a significant reduction in size of the overall ischemia and a final outcome identified in a reduction of the area that finally underwent calcaneal escharotomy [158]. It is worth noticing that the pro-angiogenic activity of NGF could be of therapeutic relevance in various types of cancer, where positive correlations between cancer stage/prognosis and tissue NGF levels have been described [160-162]. Thus, targeting the NGF/VEGF interaction system should be also regarded as a potential new strategy for anti-angiogenic therapy against cancer as well as for other angiogenesis-dependent diseases, such as diabetes, and arthritis $[162,163]$.

Table 3 Summary of clinical trials with NGF on skin ulcers

\begin{tabular}{|c|c|c|c|c|c|c|}
\hline Disease & Study type & $\begin{array}{l}\text { NGF type and } \\
\text { dosage }\end{array}$ & $\begin{array}{l}\text { Delivery } \\
\text { route }\end{array}$ & Outcome & $\begin{array}{l}\text { Side } \\
\text { effects }\end{array}$ & References \\
\hline $\begin{array}{l}\text { Diabetic } \\
\text { foot ulcers }\end{array}$ & $\begin{array}{l}\text { Three patients case } \\
\text { report. }\end{array}$ & $\begin{array}{l}\text { Mouse NGF. } 25 \mu \mathrm{g} / \text { day } \\
\text { for } 4 \text { weeks. }\end{array}$ & Topical (skin). & $\begin{array}{l}\text { Progressive restoration of nerve function and } \\
\text { relapse of ulcers within } 5-14 \text { weeks since the } \\
\text { beginning of treatment. }\end{array}$ & $\begin{array}{l}\text { Not } \\
\text { reported. }\end{array}$ & {$[154]$} \\
\hline $\begin{array}{l}\text { Vasculitic } \\
\text { ulcers }\end{array}$ & $\begin{array}{l}\text { Eight patients case } \\
\text { report. }\end{array}$ & $\begin{array}{l}\text { Mouse NGF. } 50 \text { g/day } \\
\text { for } 4 \text { weeks. }\end{array}$ & Topical (skin). & $\begin{array}{l}\text { Ulcers healing within } 8 \text { weeks in rheumatoid } \\
\text { arthritis patients }(n=4) \text {. Failure of ulcers healing in } \\
\text { systemic sclerosis patients }(n=4) \text {. }\end{array}$ & $\begin{array}{l}\text { Not } \\
\text { reported. }\end{array}$ & {$[155]$} \\
\hline \multirow[t]{2}{*}{$\begin{array}{l}\text { Pressure } \\
\text { ulcers }\end{array}$} & $\begin{array}{l}\text { Single patient case } \\
\text { study. }\end{array}$ & Mouse NGF. & Topical (skin). & Ulcer size reduced by $1 / 3$ after 15 days treatment. & $\begin{array}{l}\text { Not } \\
\text { reported. }\end{array}$ & {$[156]$} \\
\hline & $\begin{array}{l}\text { Randomized, } \\
\text { double-blind, } \\
\text { placebo-controlled } \\
\text { trial. }\end{array}$ & Mouse NGF. & Topical (skin). & Reduction of ulcer area in the 6 weeks follow-up. & $\begin{array}{l}\text { Not } \\
\text { reported. }\end{array}$ & {$[157]$} \\
\hline $\begin{array}{l}\text { Lower } \\
\text { limb crush } \\
\text { syndrome }\end{array}$ & $\begin{array}{l}\text { Single patient case } \\
\text { study. }\end{array}$ & $\begin{array}{l}\text { Mouse NGF. } 10 \mu \mathrm{g} \\
\text { every eight hours for } \\
\text { seven days. }\end{array}$ & Subcutaneous. & $\begin{array}{l}\text { Reduction of overall ischemic area. Reduction of } \\
\text { the area undergoing calcaneal escharotomy. }\end{array}$ & $\begin{array}{l}\text { Not } \\
\text { reported. }\end{array}$ & {$[158]$} \\
\hline
\end{tabular}




\section{Ophthalmology}

The use of NGF as a therapeutic in ophthalmology is perhaps the best characterized and developed, among the other possible or yet pursued clinical use (refer to Table 4 for a summary of clinical trials of NGF in ophthalmology). One of the first evidence suggesting a possible role of NGF in the visual system was reported in 1979 by Turner [164] who showed that the retinal cells of goldfish are receptive to the action of NGF. It has been reported that NGF induces modification of presynaptic elements in adult visual system $[165,166]$, prevents the shift in ocular dominance distribution of visual cortical neurons and promotes functional recovery of retinal ganglion cells (RGC) after ischemia [167], delays retinal degeneration in rodents with inherited retinopathy $[168,169]$, reduces retinal damages in rabbits with ocular hypertension [170], while injection of antibody against NGF exacerbate the damaging effect on RGC [170]. The first attempt to translate preclinical studies into clinic was based on the described presence of NGF and NGF receptors on corneal cells and structure [171175], suggesting a possible trophic influence of the neurotrophin on the ocular surface.

In the first published study about the application of NGF-eyedrops [172], severe corneal ulcers associated with anesthesia (corneal neurotrophic keratitis) were treated with purified mNGF. The results reported a rapid healing of all of the ulcers, improved corneal sensitivity and integrity and improved visual acuity. Very similar results were reported in a following study, on neurotrophic keratitis non-responsive to conventional treatments [176]. The follow-up lasted for a period ranging between 3 and 32 months after initiation of treatment and the study shows that all patients achieved complete healing of the corneal defect within a period between 12 days and 6 weeks after initiation of treatment. The study also showed that the occurrence of side effects, described as hyperemia and moderate pain in the eye and periocular area, were well tolerated and limited to the time necessary for the remission of corneal keratitis.

A study published in 2007 evaluated the effect of topical treatment with mNGF on eyes from 11 patients with neurotrophic keratopathy [177], considering in particular the possible occurrence of unpleasant side effects and the development of systemic anti-NGF as a result of the treatment protocol. All patients had healing of corneal ulcers between 9 and 43 days after initiation of treatment. The study revealed that the ocular discomfort lasted less than an hour after the instillation of eye drops and that any painful sensation disappeared, even when NGF treatments were continued after the healing of corneal ulcers. None of the patients developed systemic symptoms during treatment or during follow-up. The

Table 4 Summary of clinical trials with NGF in ophthalmology

\begin{tabular}{|c|c|c|c|c|c|c|}
\hline Disease & Study type & NGF type and dosage & $\begin{array}{l}\text { Delivery } \\
\text { route }\end{array}$ & Outcome & Side effects & References \\
\hline \multirow[t]{3}{*}{$\begin{array}{l}\text { Neurotrophic } \\
\text { keratitis }\end{array}$} & $\begin{array}{l}\text { Twelve patients } \\
\text { case report. }\end{array}$ & $\begin{array}{l}\text { Mouse NGF. Several daily } \\
\text { applications of a } 200 \mu \mathrm{g} / \mathrm{ml} \\
\text { solution for } 6 \text { weeks. }\end{array}$ & $\begin{array}{l}\text { Topical } \\
\text { (eye). }\end{array}$ & $\begin{array}{l}\text { Healing of all of the ulcers, } \\
\text { improved corneal sensitivity and } \\
\text { integrity and improved visual } \\
\text { acuity. }\end{array}$ & Not reported. & {$[172]$} \\
\hline & $\begin{array}{l}\text { Prospective, } \\
\text { noncomparative, } \\
\text { interventional } \\
\text { case series; } 43 \\
\text { patients. }\end{array}$ & $\begin{array}{l}\text { Mouse NGF. Several daily } \\
\text { applications of a } 200 \text { Hg/ml } \\
\text { solution until ulcer healing. }\end{array}$ & $\begin{array}{l}\text { Topical } \\
\text { (eye). }\end{array}$ & $\begin{array}{l}\text { Complete resolution of the } \\
\text { epithelial defect between } 12 \text { days } \\
\text { and } 6 \text { weeks of treatment. } \\
\text { Improvement of corneal sensitivity } \\
\text { and visual acuity. }\end{array}$ & $\begin{array}{l}\text { Hyperemia and } \\
\text { ocular and periocular } \\
\text { pain. }\end{array}$ & {$[176]$} \\
\hline & $\begin{array}{l}\text { Observational } \\
\text { study on } 11 \\
\text { patients. }\end{array}$ & $\begin{array}{l}\text { Mouse NGF. Several daily } \\
\text { applications of a } 200 \mu \mathrm{g} / \mathrm{ml} \\
\text { solution until ulcer healing. }\end{array}$ & $\begin{array}{l}\text { Topical } \\
\text { (eye). }\end{array}$ & $\begin{array}{l}\text { Ulcer healing between } 9 \text { and } \\
43 \text { days after initiation of } \\
\text { treatment. No development of } \\
\text { systemic anti-NGF antibodies in a } \\
\text { follow-up time of } 72 \text { months. }\end{array}$ & $\begin{array}{l}\text { Mild and transient } \\
\text { conjunctival } \\
\text { hyperemia and } \\
\text { photophobia. }\end{array}$ & {$[177]$} \\
\hline Glaucoma & $\begin{array}{l}\text { Three patients } \\
\text { case report. }\end{array}$ & $\begin{array}{l}\text { Mouse NGF. Four daily } \\
\text { applications of a } 200 \mu \mathrm{g} / \mathrm{ml} \\
\text { solution for } 3 \text { months. }\end{array}$ & $\begin{array}{l}\text { Topical } \\
\text { (eye). }\end{array}$ & $\begin{array}{l}\text { Progressive improvement in the } \\
\text { functionality of the inner retinal } \\
\text { layer and in the parameters of the } \\
\text { post-retinal neural conduction and } \\
\text { visual acuity, maintained for } \\
3 \text { months after discontinuation of } \\
\text { treatment. }\end{array}$ & $\begin{array}{l}\text { Local burning during } \\
\text { the first week of } \\
\text { treatment in a single } \\
\text { patient. }\end{array}$ & {$[178]$} \\
\hline $\begin{array}{l}\text { Bilateral age- } \\
\text { related } \\
\text { macular } \\
\text { degeneration } \\
\text { (retinopathy) }\end{array}$ & $\begin{array}{l}\text { Single case } \\
\text { study. }\end{array}$ & $\begin{array}{l}\text { Mouse NGF. Three times daily } \\
\text { applications of } 200 \mu \mathrm{g} / \mathrm{ml} \\
\text { solution for } 2 \text { separate } \\
\text { periods of } 1 \text { year and } 5 \text { years } \\
\text { in the right eye. }\end{array}$ & $\begin{array}{l}\text { Topical } \\
\text { (eye). }\end{array}$ & $\begin{array}{l}\text { Improvement in visual acuity and } \\
\text { in the amplitude of the ERG. }\end{array}$ & $\begin{array}{l}\text { Slight burning at the } \\
\text { time of application of } \\
\text { eye drops during the } \\
\text { first month of } \\
\text { treatment. }\end{array}$ & {$[179]$} \\
\hline
\end{tabular}


presence of antibodies against the mNGF in the blood was negative for all of the treated patients during the therapy and for a period of follow-up up to 72 months.

After the first approach on ocular surface pathologies, mNGF was used in clinical studies addressing the posterior segment of the eye. In a study published in 2009, the application of topical mNGF, was evaluated in three patients with advanced glaucoma, with imminent risk of loss of visual function [178]. The reported results were: progressive improvement in the functionality of the inner retinal layer and in the parameters of the postretinal neural conduction, evident during the treatment period and maintained even 3 months after discontinuation of treatment; visual acuity improved significantly in all patients where it remained unchanged for the 3month follow-up. The study also showed the substantial absence of side effects, except for the development of local burning during the first week of treatment in a single patient.

Another case report was about the use of topical mNGF to treat a patient suffering from bilateral macular degeneration (AMD) [179]. The treatment was continued for 6 years virtually uninterrupted. Checks were made on a quarterly basis and showed a clinical (improvement of visual acuity) and electrofunctional (increasing the amplitude of the ERG) improvements in the right eye, correlated with treatment. The only side effect noted was a sensation of slight burning at the time of application of eye drops during the first month of treatment.

It is worth noticing that in none of the cited studies systemic side effects attributable to the biological action of NGF itself were reported. In particular, the ocular NGF seems not to give rise to systemic effects on the perception of pain (myalgias, hyperalgesia) reported in clinical trials with systemic [87] or intra-cerebroventricular [120] administration.

\section{Novel delivery routes}

Though applied to a wide spectrum of neurological and non-neurological diseases, clinical utilization of NGF, especially when systemically administered, remains hampered by important adverse events, such as those derived from the effects of NGF on pain system. Moreover, the achievement of pharmacological concentrations in therapeutic relevant targets without affecting nontarget areas represents a further delivery challenge.

A potential approach to overcome such limitations is represented by gene therapy. Preclinical data obtained in rodents and primates indicated that ex vivo gene therapy targeted at BFC neurons were effective in improving experimentally induced cholinergic deficits [180,181]. A phase I clinical trial has been performed on 8 AD's patients, in which autologous fibroblasts were engineered to produce and secrete human NGF (hNGF) and implanted into the BFC (Table 2) [182]. Positive outcomes in behavioral scales were scored in two out of six patients that survived cell implant neurosurgery in a period ranging from six to eighteen months after implant, associated with improvement in PET scans. A second phase I trial based on in vivo NGF gene delivery, by adeno-associated virus vector (CERE-110) [183] has been set-up in 2004 (Table 2) [184]. The phase I study was a dose-escalating study to assess the safety and tolerability of CERE-110 in subjects with mild to moderate AD's. CERE-110 has passed phase I clinical testing and a multicenter phase II clinical trial has commenced [185]. In addition to the CERE-110 trial, a new, cell-based in vivo delivery system has been developed and a Phase I trial has been registered by Karolinska Institute in Sweden on AD's patients (Table 2) [186]. This delivery system is based on human retinal pigment epithelial cell line, engineered to secrete hNGF and encapsulated within a polymer membrane that is part of an implantable catheter-like device [187], and has been demonstrated to effectively prevent the loss of cholinergic neurons after fimbria transection in rats $[188,189]$. The results of the first safety and tolerability study based on such system have been recently published [187,190], demonstrating that surgical implantation and removal of devices containing NGF-secreting cells in the basal forebrain of $\mathrm{AD}$ patients are feasible, well tolerated and relatively safe, and that they do not generate NGF-related adverse events [190]. Though the system remains to be optimized in terms of long-term function of implanted cells and in the achievement of positive neurological outcomes (actually limited to 2 out of 6 patients), it seems to present advantages over other gene delivery approaches [182], since it allows the safe removal of engineered cells as well as their immune isolation from host tissues, thus protecting the allogeneic transplanted cells from host immune system rejection.

The olfactory pathway is a promising, non-invasive route for drug delivery to the brain, which has potential for the treatment of neurodegenerative diseases [191-193]. The BBB represents one of the major obstacles in drug development for brain diseases and many studies have focused on the possibility of circumventing the $\mathrm{BBB}$ for the direct central delivery of macromolecules to the central nervous system by utilizing the potential direct transport pathway from nose to brain via the olfactory region [194-196]. The intranasal delivery of NGF to the brain could indeed represent a non-invasive and safe route to achieve relevant therapeutic concentration of NGF in selected brain areas, without eliciting undesired and adverse side effects. The characterization of pharmacokinetic for intranasal delivery of NGF $[197,198]$ 
revealed that intranasal NGF rapidly spread through brain tissue without significant increasing NGF concentrations in the CSF and in the blood. Studies on animal models of AD, revealed that intranasal NGF, while exerting specific therapeutic actions on the affected cholinergic system, did not provide trophic support to sympathetic ganglia, nor did it induced the over expression of nociception neuromodulators, such as sensory neuropeptides, known to be under NGF control [197-199]. Recent studies published by the same group, characterized a form of hNGF mutated at residue $\mathrm{R} 100$, testing it both in vitro and in vivo, by intranasal delivery, in an animal model of AD $[199,200]$. Such a mutated hNGF retains the neurotrophic potential of the native NGF, without eliciting pain-related response. It would be of interest whether such a "painless" NGF variant can be validated in preclinical and hopefully future clinical trials for neurodegenerative diseases [199].

Another actually investigated route that seems to be able to deliver NGF to the brain in a safe and effective manner is the topical administration of NGF on ocular surface [201]. Animal studies have demonstrated that NGF applied on the ocular surface can reach central cholinergic neurons, which are affected in AD [201]. Moreover, ocular NGF is able to activate c-fos in several areas of the limbic system in a time-dependent manner [202] and to enhance the distribution of Ki67positive cells also expressing $\mathrm{p} 75^{\mathrm{NTR}}$ in the proliferating layer of the sub-ventricular zone, indicating that ocular NGF can activate the machinery regulating the proliferation and maturation of neuronal precursor in the brain [203]. Compared to intranasal delivery, the intraocular one appears to be less characterized, in terms of mechanisms and anatomical route for brain delivery [204]. The available data indicate that the ocular delivered NGF does not induce systemic side effects related to the systemic NGF administration, even when this is repeated for rather long time periods $[172,176,177,179]$, being able to target selected brain areas [201-203]. In a recent study on a mouse model of AD the intranasal and ocular delivery routes for hNGF administration were compared for their relative diffusion in the systemic compartment in concentration that could elicit a pain response [205]. The authors reported that intra-nasally applied hNGF was safer when compared to intra-ocular one. It should however be taken into consideration and tested whether there is a possible different biological activity of mNGF used in the majority of the ophthalmology clinical trials $[172,176,177,179]$ versus the rhNGF used in the cited comparative study [205].

To date two reports, both from the same group, investigated the clinical effects of topical ocular NGF on brain structures lying behind the retina (Table 2) $[206,207]$. In one study [206] five pediatric patients with optic gliomas (OGs) and advanced optic nerve atrophy were assessed before and after a single 10 day course of $1 \mathrm{mg}$ (total) mNGF topical administration by clinical evaluation, visual evoked potentials (VEPs), and brain magnetic resonance imaging (MRI). While not affecting tumor size, the topical mNGF improved VEPs suggesting a visual rescuing mechanism exerted by mNGF on the residual viable optic pathways. In a further study [207] a single adult patient with OG and long-standing optic nerve atrophy was treated with mNGF and the follow-up was performed by clinical, neuroradiologic, and electrophysiological tests (electroretinogram and VEPs) at the end of each treatment and 30 and 60 days later. Repeated subjective and objective improvement of visual function was recorded after mNGF treatment, which tended to deteriorate toward baseline values 60 days from the end of each mNGF treatment. Interestingly, no ocular or systemic side effects were observed throughout treatment [207].

\section{Conclusions}

Soon after its discovery, in the middle of the twentieth century, it became clear that NGF had great pharmacological potentialities, for the treatment of major central neurodegenerative diseases and of peripheral neuropathies. After preclinical characterization and clinical trials have been performed by treating AD, Parkinson's, and diabetic patients (Figure 2, Tables 1 and 2), severe limitations in the clinical use of NGF emerged, coming from its physiological action on the sensory and autonomic systems and from the high pharmacological doses needed to obtain disease improvements. Despite the discouraging results coming from trials mainly performed across the 1990's, the translational research on NGF was not stopped, widening the spectrum of diseases that could benefit from NGF-based therapy and investigating new delivery strategies, aimed at maximizing positive outcomes and limiting or fully circumventing the deleterious side effects described in earlier clinical trials. Today we know that epithelial derangements based on poor neurotrophism could be safely treated with topical NGF, while a wide spectrum of CNS and PNS diseases will probably benefit from NGF therapy, once intranasal or gene delivery systems will be finally set-up and fully translated into clinical practice. A further challenge, in conclusion, is represented by the increasing knowledge on the role of NGF in immune system regulation, opening a promising field for development of innovative NGF-based therapies in the care of, in example, chronic inflammatory or autoimmune diseases, and a novel and challenging aspect in the NGF saga.

\section{Abbreviations}

AD: Alzheimer's disease; BBB: Blood-brain barrier; BFC: Basal forebrain complex; CGRP: Calcitonin gene-related peptide; CIPN: Chemotherapyinduced peripheral neurotoxicity; CNS: Central nervous system; CSF: Cerebro- 
spinal fluid; DRG: Dorsal root ganglion; ERK: Extracellular signal-regulated kinase; HIV: Human immunodeficiency virus; hNGF: Human NGF; ICV: Intracerebro-ventricular; MAPK: Mitogen activated protein kinase; mNGF: Murine NGF; MRI: Magnetic resonance imaging; NF-KB: Nuclear factor kappa-lightchain-enhancer of activated B cells; NGF: Nerve growth factor; OG: Optic glioma; p75 NTR: p75 pan-neurotrophin receptor; PD: Parkinson's disease; PI3K: Phosphatidylinositol 3-kinase; PLC: Phospholipase C; PNS: Peripheral nervous system; RA: Rheumatoid arthritis; RGC: Retinal ganglion cell: rhNGF: Recombinant human NGF; SP: Substance P; SSc: Systemic sclerosis; TBI: Traumatic brain injury; TH: Tyrosine hydroxylase; TrkA: Tropomyosin kinase receptor A; VEGF: Vascular-endothelial growth factor; VEPs: Visual evoked potentials.

\section{Competing interests}

The authors declare that they have no competing interests.

\section{Authors' contributions}

LA conceived, drafted and reviewed the manuscript. MLR drafted and reviewed the manuscript. PB drafted and reviewed the manuscript. LM conceived, drafted and reviewed the manuscript. All authors read and approved the final manuscript.

\section{Author details}

${ }^{1}$ Cellular Biology and Neurobiology Institute, CNR, via del Fosso di Fiorano 64, 00143, Rome, Italy. ${ }^{2}$ Institute of Translational Pharmacology, National Research Council (CNR), via Fosso del Cavaliere 100, 00136, Rome, Italy.

Received: 19 July 2012 Accepted: 21 November 2012

Published: 29 November 2012

\section{References}

1. Ebendal T: Function and evolution in the NGF family and its receptors. J Neurosci Res 1992, 32:461-470.

2. Aloe L, Bracci-Laudiero L, Bonini S, Manni L: The expanding role of nerve growth factor: from neurotrophic activity to immunologic diseases. Allergy 1997, 52:883-894.

3. Hallbook F: Evolution of the vertebrate neurotrophin and Trk receptor gene families. Curr Opin Neurobiol 1999 Oct, 9:616-621.

4. Fahnestock M, Yu G, Michalski B, Mathew S, Colquhoun A, Ross GM, Coughlin MD: The nerve growth factor precursor proNGF exhibits neurotrophic activity but is less active than mature nerve growth factor. J Neurochem 2004, 89:581-592.

5. Fahnestock M, Yu G, Coughlin MD: ProNGF: a neurotrophic or an apoptotic molecule? Prog Brain Res 2004, 146:101-110.

6. Huang EJ, Reichardt LF: TRK receptors: roles in neuronal signal transduction. Annu Rev Biochem 2003, 72:609-642. 609-642.

7. Klesse LJ, Parada LF: Trks: signal transduction and intracellular pathways. Microsc Res Tech 1999, 45:210-216.

8. Chao MV, Rajagopal R, Lee FS: Neurotrophin signalling in health and disease. Clin Sci (Lond) 2006, 110:167-173.

9. Reichardt LF: Neurotrophin-regulated signalling pathways. Philos $\operatorname{Trans} R$ Soc Lond B Biol Sci 2006, 361:1545-1564.

10. Friedman WJ, Greene LA: Neurotrophin signaling via Trks and p75. Exp Cell Res 1999, 253:131-142.

11. Schor NF: The p75 neurotrophin receptor in human development and disease. Prog Neurobiol 2005, 77:201-214.

12. Miller $F D$, Kaplan DR: Neurotrophin signalling pathways regulating neuronal apoptosis. Cell Mol Life Sci 2001, 58:1045-1053.

13. Levi-Montalcini R: The nerve growth factor: thirty-five years later. Science 1987, 237:1154-1162.

14. Cowan WM: Viktor Hamburger and Rita Levi-Montalcini: the path to the discovery of nerve growth factor. Annu Rev Neurosci 2001, 24:551-600.

15. Rush RA, Chie E, Liu D, Tafreshi A, Zettler C, Zhou XF: Neurotrophic factors are required by mature sympathetic neurons for survival, transmission and connectivity. Clin Exp Pharmacol Physiol 1997, 24:549-555.

16. Alleva E, Aloe L, Bigi S: An updated role for nerve growth factor in neurobehavioural regulation of adult vertebrates. Rev Neurosci 1993, $4: 41-62$

17. Otten U, Schwab M, Gagnon C, Thoenen H: Selective induction of tyrosine hydroxylase and dopamine beta-hydroxylase by nerve growth factor: comparison between adrenal medulla and sympathetic ganglia of adult and newborn rats. Brain Res 1977, 133:291-303.

18. Mearow KM, Kril Y: Anti-NGF treatment blocks the upregulation of NGF receptor mRNA expression associated with collateral sprouting of rat dorsal root ganglion neurons. Neurosci Lett 1995, 184:55-58. 55-58.

19. Verge VM, Richardson PM, Wiesenfeld-Hallin Z, Hokfelt T: Differential influence of nerve growth factor on neuropeptide expression in vivo: a novel role in peptide suppression in adult sensory neurons. J Neurosci 1995, 15:2081-2096.

20. Mearowa KM, Kril Y: Anti-NGF treatment blocks the upregulation of NGF receptor mRNA expression associated with collateral sprouting of rat dorsal root ganglion neurons. Neurosci Lett 1995, 184:55-58.

21. Lindsay RM, Harmar AJ: Nerve growth factor regulates expression of neuropeptide genes in adult sensory neurons. Nature 1989, 337:362-364.

22. MCAllister AK: Neurotrophins and neuronal differentiation in the central nervous system. Cell Mol Life Sci 2001, 58:1054-1060.

23. Dreyfus CF: Effects of nerve growth factor on cholinergic brain neurons. Trends Pharmacol Sci 1989, 10:145-149.

24. Allen SJ, Dawbarn D: Clinical relevance of the neurotrophins and their receptors. Clin Sci (Lond) 2006, 110:175-191.

25. Spillantini MG, Aloe L, Alleva E, De Simone R, Goedert M, Levi-Montalcini R Nerve growth factor mRNA and protein increase in hypothalamus in a mouse model of aggression. Proc Natl Acad Sci USA 1989, 86:8555-8559.

26. Aloe $L$, Alleva $E$, De Simone R: Changes of NGF level in mouse hypothalamus following intermale aggressive behaviour: biological and immunohistochemical evidence. Behav Brain Res 1990, 39:53-61.

27. Taglialatela G, Angelucci L, Scaccianoce S, Foreman PJ, Perez-Polo JR: Nerve growth factor modulates the activation of the hypothalamo-pituitaryadrenocortical axis during the stress response. Endocrinology 1991 129:2212-2218.

28. Scaccianoce S, Cigliana G, Nicolai R, Muscolo LA, Porcu A, Navarra D, Perez Polo JR, Angelucci L: Hypothalamic involvement in the activation of the pituitary-adrenocortical axis by nerve growth factor. Neuroendocrinology 1993, 58:202-209.

29. Manni L, Di Fausto V, Fiore M, Aloe L: Repeated restraint and nerve growth factor administration in male and female mice: effect on sympathetic and cardiovascular mediators of the stress response. Curr Neurovasc Res 2008, 5:1-12.

30. Aloe L: Nerve growth factor and neuroimmune responses: basic and clinical observations. Arch Physiol Biochem 2001, 109:354-356.

31. Bonini S, Lambiase A, Bonini S, Levi-Schaffer F, Aloe L: Nerve growth factor: an important molecule in allergic inflammation and tissue remodelling. Int Arch Allergy Immunol 1999, 118:159-162.

32. Aloe $L$, Levi-Montalcini R: Mast cells increase in tissues of neonatal rats injected with the nerve growth factor. Brain Res 1977, 133:358-366.

33. Aloe $L$ : The effect of nerve growth factor and its antibody on mast cells in vivo. J Neuroimmunol 1988, 18:1-12.

34. Auffray I, Chevalier S, Froger J, Izac B, Vainchenker W, Gascan H, Coulombel $L$ : Nerve growth factor is involved in the supportive effect by bone marrow-derived stromal cells of the factor-dependent human cell line UT-7. Blood 1996, 88:1608-1618.

35. Bracci-Laudiero L, Celestino D, Starace G, Antonelli A, Lambiase A, Procoli A, Rumi C, Lai M, Picardi A, Ballatore G, et al: CD34-positive cells in human umbilical cord blood express nerve growth factor and its specific receptor TrkA. J Neuroimmunol 2003, 136:130-139.

36. Cattoretti G, Schiro R, Orazi A, Soligo D, Colombo MP: Bone marrow stroma in humans: anti-nerve growth factor receptor antibodies selectively stain reticular cells in vivo and in vitro. Blood 1993, 81:1726-1738.

37. Chevalier S, Praloran V, Smith C, MacGrogan D, Ip NY, Yancopoulos GD, Brachet P, Pouplard A, Gascan H: Expression and functionality of the trkA proto-oncogene product/NGF receptor in undifferentiated hematopoietic cells. Blood 1994, 83:1479-1485.

38. Bischoff SC, Dahinden CA: Effect of nerve growth factor on the release of inflammatory mediators by mature human basophils. Blood 1992 79:2662-2669

39. Burgi B, Otten UH, Ochensberger B, Rihs S, Heese K, Ehrhard PB, Ibanez CF, Dahinden CA: Basophil priming by neurotrophic factors. Activation through the trk receptor. J Immunol 1996, 157:5582-5588.

40. Gibbs BF, Zillikens D, Grabbe J: Nerve growth factor influences IgE-mediated human basophil activation: functional properties and 
intracellular mechanisms compared with IL-3. Int Immunopharmacol 2005, 5:735-747.

41. Sin AZ, Roche EM, Togias A, Lichtenstein LM, Schroeder JT: Nerve growth factor or IL-3 induces more IL-13 production from basophils of allergic subjects than from basophils of nonallergic subjects. J Allergy Clin Immunol 2001, 108:387-393.

42. Takafuji S, Bischoff SC, De Weck AL, Dahinden CA: Opposing effects of tumor necrosis factor-alpha and nerve growth factor upon leukotriene C4 production by human eosinophils triggered with $\mathrm{N}$-formyl-methionylleucyl-phenylalanine. Eur J Immunol 1992, 22:969-974.

43. Beigelman A, Levy J, Hadad N, Pinsk V, Haim A, Fruchtman Y, Levy R: Abnormal neutrophil chemotactic activity in children with congenital insensitivity to pain with anhidrosis (CIPA): the role of nerve growth factor. Clin Immunol 2009, 130:365-372.

44. Boyle MD, Lawman MJ, Gee AP, Young M: Nerve growth factor: a chemotactic factor for polymorphonuclear leukocytes in vivo. J Immunol $1985,134: 564-568$.

45. Gee AP, Boyle MD, Munger KL, Lawman MJ, Young M: Nerve growth factor: stimulation of polymorphonuclear leukocyte chemotaxis in vitro. Proc Natl Acad Sci USA 1983, 80:7215-7218.

46. Kannan Y, Ushio H, Koyama H, Okada M, Oikawa M, Yoshihara T, Kaneko M, Matsuda $\mathrm{H}$ : $2.5 \mathrm{~S}$ nerve growth factor enhances survival, phagocytosis, and superoxide production of murine neutrophils. Blood 1991 , 77:1320-1325

47. Bracci-Laudiero L, Aloe L, Caroleo MC, Buanne P, Costa N, Starace G, Lundeberg T: Endogenous NGF regulates CGRP expression in human monocytes, and affects HLA-DR and CD86 expression and IL-10 production. Blood 2005, 106:3507-3514.

48. Brodie C, Gelfand EW: Functional nerve growth factor receptors on human B lymphocytes. Interaction with IL-2. J Immunol 1992, 148:3492-3497.

49. Melamed I, Kelleher CA, Franklin RA, Brodie C, Hempstead B, Kaplan D, Gelfand EW: Nerve growth factor signal transduction in human B lymphocytes is mediated by gp140trk. Eur J Immunol 1996, 26:1985-1992.

50. Otten $U$, Ehrhard P, Peck R: Nerve growth factor induces growth and differentiation of human B lymphocytes. Proc Natl Acad Sci USA 1989, 86:10059-10063.

51. Torcia M, Bracci-Laudiero L, Lucibello M, Nencioni L, Labardi D, Rubartelli A, Cozzolino F, Aloe L, Garaci E: Nerve growth factor is an autocrine survival factor for memory B lymphocytes. Cell 1996, 85:345-356.

52. Ehrhard PB, Erb P, Graumann U, Otten U: Expression of nerve growth factor and nerve growth factor receptor tyrosine kinase Trk in activated CD4-positive T-cell clones. Proc Natl Acad Sci USA 1993, 90:10984-10988.

53. Lambiase A, Bracci-Laudiero L, Bonini S, Bonini S, Starace G, D'Elios MM, De Carli M, Aloe L: Human CD4+ T cell clones produce and release nerve growth factor and express high-affinity nerve growth factor receptors. J Allergy Clin Immunol 1997, 100:408-414.

54. Noga O, Peiser M, Altenahr M, Knieling H, Wanner R, Hanf G, Grosse R, Suttorp N: Differential activation of dendritic cells by nerve growth factor and brain-derived neurotrophic factor. Clin Exp Allergy 2007, 37:1701-1708.

55. Caroleo MC, Costa N, Bracci-Laudiero L, Aloe L: Human monocyte/ macrophages activate by exposure to LPS overexpress NGF and NGF receptors. J Neuroimmunol 2001, 113:193-201.

56. Ehrhard PB, Ganter U, Stalder A, Bauer J, Otten U: Expression of functional trk protooncogene in human monocytes. Proc Natl Acad Sci USA 1993, 90:5423-5427.

57. Ia Sala A, Corinti S, Federici M, Saragovi HU, Girolomoni G: Ligand activation of nerve growth factor receptor TrkA protects monocytes from apoptosis. J Leukoc Biol 2000, 68:104-110.

58. Ma W, Dumont Y, Vercauteren F, Quirion R: Lipopolysaccharide induces calcitonin gene-related peptide in the RAW264.7 macrophage cell line. Immunology 2010, 130:399-409.

59. Thorpe LW, Stach RW, Hashim GA, Marchetti D, Perez-Polo JR: Receptors for nerve growth factor on rat spleen mononuclear cells. J Neurosci Res 1987, 17:128-134

60. Seidel MF, Herguijuela M, Forkert R, Otten U: Nerve growth factor in rheumatic diseases. Semin Arthritis Rheum 2010, 40:109-126.

61. Scuri M, Samsell L, Piedimonte G: The role of neurotrophins in inflammation and allergy. Inflamm Allergy Drug Targets 2010, 9:173-180.

62. Kawamoto K, Matsuda H: Nerve growth factor and wound healing. Prog Brain Res 2004, 146:369-384
63. Linker R, Gold R, Luhder F: Function of neurotrophic factors beyond the nervous system: inflammation and autoimmune demyelination. Crit Rev Immunol 2009, 29:43-68.

64. Yuen EC, Howe CL, Li Y, Holtzman DM, Mobley WC: Nerve growth factor and the neurotrophic factor hypothesis. Brain Dev 1996, 18:362-368.

65. Mendell LM: Neurotrophin action on sensory neurons in adults: an extension of the neurotrophic hypothesis. Pain 1999, (Suppl 6):S127-S132.

66. Hellweg R, Hartung HD: Endogenous levels of nerve growth factor (NGF) are altered in experimental diabetes mellitus: a possible role for NGF in the pathogenesis of diabetic neuropathy. J Neurosci Res 1990, 26:258-267.

67. Hellweg R, Raivich G, Hartung HD, Hock C, Kreutzberg GW: Axonal transport of endogenous nerve growth factor (NGF) and NGF receptor in experimental diabetic neuropathy. Exp Neurol 1994, 130:24-30.

68. Apfel SC, Kessler JA: Neurotrophic factors in the therapy of peripheral neuropathy. Baillieres Clin Neurol 1995, 4:593-606.

69. McMahon SB, Priestley JV: Peripheral neuropathies and neurotrophic factors: animal models and clinical perspectives. Curr Opin Neurobio/ 1995, 5:616-624.

70. Anand P: Neurotrophins and peripheral neuropathy. Philos Trans $R$ SoC Lond B Biol Sci 1996, 351:449-454.

71. Riaz SS, Tomlinson DR: Neurotrophic factors in peripheral neuropathies: pharmacological strategies. Prog Neurobiol 1996, 49:125-143.

72. Sima AA: New insights into the metabolic and molecular basis for diabetic neuropathy. Cell Mol Life Sci 2003, 60:2445-2464.

73. Sima AA, Kamiya H: Diabetic neuropathy differs in type 1 and type 2 diabetes. Ann N Y Acad Sci 2006, 1084:235-249.

74. Schmidt RE, Modert CW, Yip HK, Johnson EMJ: Retrograde axonal transport of intravenously administered 125I-nerve growth factor in rats with streptozotocin-induced diabetes. Diabetes 1983, 32:654-663.

75. Faradji $\vee$, Sotelo J: Low serum levels of nerve growth factor in diabetic neuropathy. Acta Neurol Scand 1990, 81:402-406.

76. Fernyhough P, Diemel LT, Brewster WJ, Tomlinson DR: Altered neurotrophin mRNA levels in peripheral nerve and skeletal muscle of experimentally diabetic rats. J Neurochem 1995, 64:1231-1237.

77. Ji RR, Samad TA, Jin SX, Schmoll R, Woolf CJ: p38 MAPK activation by NGF in primary sensory neurons after inflammation increases TRPV1 levels and maintains heat hyperalgesia. Neuron 2002, 36:57-68.

78. Nicol GD, Vasko MR: Unraveling the story of NGF-mediated sensitization of nociceptive sensory neurons: ON or OFF the Trks? Mol Interv 2007, 7:26-41.

79. Purves T, Middlemas A, Agthong S, Jude EB, Boulton AJ, Fernyhough P, Tomlinson DR: A role for mitogen-activated protein kinases in the etiology of diabetic neuropathy. FASEB J 2001, 15:2508-2514.

80. Diemel LT, Brewster WJ, Fernyhough P, Tomlinson DR: Expression of neuropeptides in experimental diabetes; effects of treatment with nerve growth factor or brain-derived neurotrophic factor. Brain Res Mol Brain Res 1994, 21:171-175.

81. Sango K, Verdes JM, Hikawa N, Horie H, Tanaka S, Inoue S, Sotelo JR, Takenaka T: Nerve growth factor (NGF) restores depletions of calcitonin gene-related peptide and substance $P$ in sensory neurons from diabetic mice in vitro. J Neurol Sci 1994, 126:1-5

82. Apfel SC: Neurotrophic factors in the therapy of diabetic neuropathy. Am J Med 1999, 107:34S-42S

83. Apfel SC, Arezzo JC, Brownlee M, Federoff H, Kessler JA: Nerve growth factor administration protects against experimental diabetic sensory neuropathy. Brain Res 1994, 634:7-12.

84. Rogers BC: Development of recombinant human nerve growth factor (rhNGF) as a treatment for peripheral neuropathic disease. Neurotoxicology 1996, 17:865-870.

85. Petty BG, Cornblath DR, Adornato BT, Chaudhry V, Flexner C, Wachsman M, Sinicropi D, Burton LE, Peroutka SJ: The effect of systemically administered recombinant human nerve growth factor in healthy human subjects. Ann Neurol 1994, 36:244-246.

86. Apfel SC, Kessler JA, Adornato BT, Litchy WJ, Sanders C, Rask CA Recombinant human nerve growth factor in the treatment of diabetic polyneuropathy. NGF study group. Neurology 1998, 51:695-702.

87. Apfel SC: Nerve growth factor for the treatment of diabetic neuropathy: what went wrong, what went right, and what does the future hold? Int Rev Neurobiol 2002, 50:393-413.

88. Apfel SC, Schwartz S, Adornato BT, Freeman R, Biton V, Rendell M, Vinik A, Giuliani M, Stevens JC, Barbano R, Dyck PJ: Efficacy and safety of 
recombinant human nerve growth factor in patients with diabetic polyneuropathy: a randomized controlled trial. rhNGF clinical investigator group. JAMA 2000, 284:2215-2221.

89. Berger JR, Nath A: Remedies for HIV-associated peripheral neuropathy. Neurology 2000, 54:2037-2038.

90. Peltier AC, Russell JW: Recent advances in drug-induced neuropathies. Curr Opin Neurol 2002, 15:633-638.

91. Simpson DM, Haidich AB, Schifitto G, Yiannoutsos CT, Geraci AP, McArthur $J C$, Katzenstein DA: Severity of HIV-associated neuropathy is associated with plasma HIV-1 RNA levels. AIDS 2002, 16:407-412.

92. A phase II, double-blind trial of recombinant human nerve growth factor for treatment of hiv-associated sensory neuropathy. http://clinicaltrials. gov/ct2/show/study/NCT00000842.

93. McArthur JC, Yiannoutsos C, Simpson DM, Adornato BT, Singer EJ, Hollander $H$, Marra C, Rubin M, Cohen BA, Tucker T, et al: A phase II trial of nerve growth factor for sensory neuropathy associated with HIV infection. AIDS Clinical Trials Group Team 291 [see comments] [published erratum appears in Neurology 2000 Jul 13;55(1):162]. Neurology 2000, 54:1080-1088.

94. Schifitto G, Yiannoutsos C, Simpson DM, Adornato BT, Singer EJ, Hollander H, Marra CM, Rubin M, Cohen BA, Tucker T, et al: Long-term treatment with recombinant nerve growth factor for HIV-associated sensory neuropathy. Neurology 2001, 57:1313-1316.

95. Alberts DS, Noel JK: Cisplatin-associated neurotoxicity: can it be prevented? Anticancer Drugs 1995, 6:369-383.

96. Konings PN, Makkink WK, van Delft AM, Ruigt GS: Reversal by NGF of cytostatic drug-induced reduction of neurite outgrowth in rat dorsal root ganglia in vitro. Brain Res 1994, 640:195-204.

97. Apfel SC, Arezzo JC, Lipson L, Kessler JA: Nerve growth factor prevents experimental cisplatin neuropathy. Ann Neurol 1992, 31:76-80.

98. Hayakawa K, Sobue G, Itoh T, Mitsuma T: Nerve growth factor prevents neurotoxic effects of cisplatin, vincristine and taxol, on adult rat sympathetic ganglion explants in vitro. Life Sci 1994, 55:519-525.

99. Schmidt Y, Unger JW, Bartke I, Reiter R: Effect of nerve growth factor on peptide neurons in dorsal root ganglia after taxol or cisplatin treatment and in diabetic (db/db) mice. Exp Neurol 1995, 132:16-23.

100. Hayakawa K, Itoh T, Niwa H, Mutoh T, Sobue G: NGF prevention of neurotoxicity induced by cisplatin, vincristine and taxol depends on toxicity of each drug and NGF treatment schedule: in vitro study of adult rat sympathetic ganglion explants. Brain Res 1998 794:313-319.

101. Aloe L, Manni L, Properzi F, De Santis S, Fiore M: Evidence that nerve growth factor promotes the recovery of peripheral neuropathy induced in mice by cisplatin: behavioral, structural and biochemical analysis. Auton Neurosci 2000, 86:84-93.

102. Cavaletti G, Bogliun G, Marzorati L, Zincone A, Piatti M, Colombo N, Franchi D, La Presa MT, Lissoni A, Buda A, et al: Early predictors of peripheral neurotoxicity in cisplatin and paclitaxel combination chemotherapy. Ann Oncol 2004, 15:1439-1442.

103. Facer P, Mann D, Mathur R, Pandya S, Ladiwala U, Singhal B, Hongo J, Sinicropi DV, Terenghi G, Anand P: Do nerve growth factor-related mechanisms contribute to loss of cutaneous nociception in leprosy? Pain 2000, 85:231-238.

104. Anand P, Pandya S, Ladiwala U, Singhal B, Sinicropi DV, Williams-Chestnut RE: Depletion of nerve growth factor in leprosy. Lancet 1994, 344:129-130.

105. Facer P, Mathur R, Pandya SS, Ladiwala U, Singhal BS, Anand P: Correlation of quantitative tests of nerve and target organ dysfunction with skin immunohistology in leprosy. Brain 1998, 121(Pt 12):2239-2247.

106. Anand P: Nerve growth factor regulates nociception in human health and disease. Br J Anaesth 1995, 75:201-208.

107. Fischer W, Wictorin K, Bjorklund A, Williams LR, Varon S, Gage FH: Amelioration of cholinergic neuron atrophy and spatial memory impairment in aged rats by nerve growth factor. Nature 1987, 329:65-68.

108. Hefti F: Nerve growth factor promotes survival of septal cholinergic neurons after fimbrial transections. J Neurosci 1986, 6:2155-2162.

109. Kromer LF: Nerve growth factor treatment after brain injury prevents neuronal death. Science 1987, 235:214-216.

110. Tuszynski MH, U HS, Amaral DG, Gage FH: Nerve growth factor infusion in the primate brain reduces lesion-induced cholinergic neuronal degeneration. J Neurosci 1990, 10:3604-3614.
111. Tuszynski MH, Sang H, Yoshida K, Gage FH: Recombinant human nerve growth factor infusions prevent cholinergic neuronal degeneration in the adult primate brain. Ann Neurol 1991, 30:625-636.

112. Rossner S, Ueberham U, Schliebs R, Perez-Polo JR, Bigl V: p75 and TrkA receptor signaling independently regulate amyloid precursor protein mRNA expression, isoform composition, and protein secretion in PC12 cells. J Neurochem 1998, 71:757-766.

113. Rossner S, Ueberham U, Schliebs R, Perez-Polo JR, Bigl V: The regulation of amyloid precursor protein metabolism by cholinergic mechanisms and neurotrophin receptor signaling. Prog Neurobiol 1998, 56:541-569.

114. Tian L, Guo R, Yue X, Lv Q, Ye X, Wang Z, Chen Z, Wu B, Xu G, Liu X: Intranasal administration of nerve growth factor ameliorate beta-amyloid deposition after traumatic brain injury in rats. Brain Res 2012, 1440:47-55.

115. Nuydens R, Dispersyn G, de Jong M, van den Kieboom G, Borgers M, Geerts $\mathrm{H}$ : Aberrant tau phosphorylation and neurite retraction during NGF deprivation in PC12 cells. Biochem Biophys Res Commun 1997, 240:687-691.

116. Zhang ZH, Xi GM, Li WC, Ling HY, Qu P, Fang XB: Cyclic-AMP response element binding protein and tau are involved in the neuroprotective mechanisms of nerve growth factor during focal cerebral ischemia/reperfusion in rats. J Clin Neurosci 2010, 17:353-356.

117. Scott SA, Mufson EJ, Weingartner JA, Skau KA, Crutcher KA: Nerve growth factor in Alzheimer's disease: increased levels throughout the brain coupled with declines in nucleus basalis. J Neurosci 1995, 15:6213-6221.

118. Pan W, Banks WA, Kastin AJ: Permeability of the blood-brain barrier to neurotrophins. Brain Res 1998, 788:87-94.

119. Olson L, Nordberg A, von Holst H, Backman L, Ebendal T, Alafuzoff I, Amberla K, Hartvig P, Herlitz A, Lilja A, et al: Nerve growth factor affects 11C-nicotine binding, blood flow, EEG, and verbal episodic memory in an Alzheimer patient (case report). J Neural Transm Park Dis Dement Sect 1992, 4:79-95.

120. Eriksdotter Jonhagen $M$, Nordberg A, Amberla K, Backman L, Ebendal T, Meyerson B, Olson L, Seiger, Shigeta M, Theodorsson E, et al: Intracerebroventricular infusion of nerve growth factor in three patients with Alzheimer's disease. Dement Geriatr Cogn Disord 1998, 9:246-257.

121. Olson L, Backlund EO, Ebendal T, Freedman R, Hamberger B, Hansson P, Hoffer B, Lindblom U, Meyerson B, Stromberg I, et al: Intraputaminal infusion of nerve growth factor to support adrenal medullary autografts in Parkinson's disease. One-year follow-up of first clinical trial. Arch Neurol 1991, 48:373-381.

122. Chiaretti A, Antonelli A, Genovese O, Fernandez E, Giuda D, Mariotti P, Riccardi R: Intraventricular nerve growth factor infusion improves cerebral blood flow and stimulates doublecortin expression in two infants with hypoxic-ischemic brain injury. Neurol Res 2008, 30:223-228.

123. Chiaretti A, Genovese O, Riccardi R, Di Rocco C, Di Giuda D, Mariotti P, Pulitano S, Piastra M, Polidori G, Colafati GS, Aloe L: Intraventricular nerve growth factor infusion: a possible treatment for neurological deficits following hypoxic-ischemic brain injury in infants. Neurol Res 2005, 27:741-746

124. Chiaretti A, Piastra M, Polidori G, Di Rocco C, Caresta E, Antonelli A, Amendola T, Aloe L: Correlation between neurotrophic factor expression and outcome of children with severe traumatic brain injury. Intensive Care Med 2003, 29:1329-1338.

125. Date I, Ohmoto T: Neural transplantation and trophic factors in Parkinson's disease: special reference to chromaffin cell grafting, NGF support from pretransected peripheral nerve, and encapsulated dopamine-secreting cell grafting. Exp Neurol 1996, 137:333-344.

126. Olson L, Backman L, Ebendal T, Eriksdotter-Jonhagen M, Hoffer B, Humpel C, Freedman R, Giacobini M, Meyerson B, Nordberg A, et al: Role of growth factors in degeneration and regeneration in the central nervous system; clinical experiences with NGF in Parkinson's and Alzheimer's diseases. J Neurol 1994, 242:S12-S15.

127. Lindvall O, Backlund EO, Farde L, Sedvall G, Freedman R, Hoffer B, Nobin A, Seiger A, Olson L: Transplantation in Parkinson's disease: two cases of adrenal medullary grafts to the putamen. Ann Neurol 1987, 22:457-468.

128. Backlund EO, Granberg PO, Hamberger B, Knutsson E, Martensson A, Sedvall $\mathrm{G}$, Seiger A, Olson L: Transplantation of adrenal medullary tissue to striatum in parkinsonism. First clinical trials. J Neurosurg 1985, 62:169-173.

129. Herrera-Marschitz M, Stromberg I, Olsson D, Ungerstedt U, Olson L: Adrenal medullary implants in the dopamine-denervated rat striatum. II. Acute 
behavior as a function of graft amount and location and its modulation by neuroleptics. Brain Res 1984, 297:53-61.

130. Stromberg I, Herrera-Marschitz M, Hultgren L, Ungerstedt U, Olson L: Adrenal medullary implants in the dopamine-denervated rat striatum. I. Acute catecholamine levels in grafts and host caudate as determined by HPLC-electrochemistry and fluorescence histochemical image analysis. Brain Res 1984, 297:41-51.

131. Holtzman DM, Sheldon RA, Jaffe W, Cheng Y, Ferriero DM: Nerve growth factor protects the neonatal brain against hypoxic-ischemic injury. Ann Neurol 1996, 39:114-122.

132. Di Marco E, Marchisio PC, Bondanza S, Franzi AT, Cancedda R, De Luca M: Growth-regulated synthesis and secretion of biologically active nerve growth factor by human keratinocytes. J Biol Chem 1991, 266:21718-21722.

133. Pincelli C, Sevignani C, Manfredini R, Grande A, Fantini F, Bracci-Laudiero L, Aloe L, Ferrari S, Cossarizza A, Giannetti A: Expression and function of nerve growth factor and nerve growth factor receptor on cultured keratinocytes. J Invest Dermatol 1994, 103:13-18.

134. Pincelli C, Marconi A: Autocrine nerve growth factor in human keratinocytes. J Dermatol Sci 2000, 22:71-79.

135. Tuveri MA, Passiu G, Mathieu A, Aloe L: Nerve growth factor and mast cell distribution in the skin of patients with systemic sclerosis. Clin Exp Rheumatol 1993, 11:319-322.

136. Woolf CJ, Ma QP, Allchorne A, Poole S: Peripheral cell types contributing to the hyperalgesic action of nerve growth factor in inflammation. J Neurosci 1996, 16:2716-2723.

137. Bull HA, Leslie TA, Chopra S, Dowd PM: Expression of nerve growth factor receptors in cutaneous inflammation. Br J Dermatol 1998, 139:776-783.

138. Antunes SL, Sarno EN, Holmkvist G, Johansson O: A comparison of the expression of NGFr, PGP 9.5 and NSE in cutaneous lesions of patients with early leprosy using immunohistochemistry. Int J Lepr Other Mycobact Dis 1997, 65:357-365.

139. Terenghi G, Mann D, Kopelman PG, Anand P: trkA and trkC expression is increased in human diabetic skin. Neurosci Lett 1997, 228:33-36.

140. Matsuda H, Koyama H, Sato H, Sawada J, Itakura A, Tanaka A, Matsumoto M, Konno K, Ushio H, Matsuda K: Role of nerve growth factor in cutaneous wound healing: accelerating effects in normal and healing-impaired diabetic mice. J Exp Med 1998, 187:297-306.

141. Raychaudhuri SP, Jiang WY, Farber EM: Psoriatic keratinocytes express high levels of nerve growth factor. Acta Derm Venereol 1998, 78:84-86.

142. Artuc M, Hermes B, Steckelings UM, Grutzkau A, Henz BM: Mast cells and their mediators in cutaneous wound healing--active participants or innocent bystanders? Exp Dermatol 1999, 8:1-16.

143. Sivilia S, Paradisi M, D'Intino G, Fernandez M, Pirondi S, Lorenzini L, Calza L: Skin homeostasis during inflammation: a role for nerve growth factor. Histol Histopathol 2008, 23:1-10.

144. Chen WP, Chang YC, Hsieh ST: Trophic interactions between sensory nerves and their targets. J Biomed SCi 1999, 6:79-85.

145. Raud J, Lundeberg T, Brodda-Jansen G, Theodorsson E, Hedqvist P: Potent anti-inflammatory action of calcitonin gene-related peptide. Biochem Biophys Res Commun 1991, 180:1429-1435.

146. Newbold P, Brain SD: The modulation of inflammatory oedema by calcitonin gene-related peptide. Br J Pharmacol 1993, 108:705-710. 705-710.

147. Kahler CM, Sitte BA, Reinisch N, Wiedermann CJ: Stimulation of the chemotactic migration of human fibroblasts by substance $P$. Eur J Pharmacol 1993 Nov 16, 249:281-286.

148. Amann R, Egger T, Schuligoi R: The tachykinin NK(1) receptor antagonist SR140333 prevents the increase of nerve growth factor in rat paw skin induced by substance P or neurogenic inflammation. Neuroscience 2000, 100:611-615. 611-615.

149. Burbach GJ, Kim KH, Zivony AS, Kim A, Aranda J, Wright S, Naik SM, Caughman SW, Ansel JC, Armstrong CA: The neurosensory tachykinins substance $\mathrm{P}$ and neurokinin $\mathrm{A}$ directly induce keratinocyte nerve growth factor. J Invest Dermatol 2001, 117:1075-1082.

150. Amann R, Schuligoi R: Beta adrenergic inhibition of capsaicin-induced, NK1 receptor-mediated nerve growth factor biosynthesis in rat skin. Pain 2004, 112:76-82.

151. Galkowska H, Olszewski WL, Wojewodzka U, Rosinski G, Karnafel W: Neurogenic factors in the impaired healing of diabetic foot ulcers. J Surg Res 2006, 134:252-258.
152. Peters EM, Raap U, Welker P, Tanaka A, Matsuda H, Pavlovic-Masnicosa S, Hendrix S, Pincelli C: Neurotrophins act as neuroendocrine regulators of skin homeostasis in health and disease. Horm Metab Res 2007, 39:110-124.

153. Li AK, Koroly MJ, Schattenkerk ME, Malt RA, Young M: Nerve growth factor: acceleration of the rate of wound healing in mice. Proc Natl Acad Sci USA 1980, 77:4379-4381.

154. Generini S, Tuveri MA, Matucci Cerinic M, Mastinu F, Manni L, Aloe L: Topical application of nerve growth factor in human diabetic foot ulcers. A study of three cases. Exp Clin Endocrinol Diabetes 2004, 112:542-544.

155. Tuveri M, Generini S, Matucci-Cerinic M, Aloe L: NGF, a useful tool in the treatment of chronic vasculitic ulcers in rheumatoid arthritis. Lancet 2000, 356:1739-1740

156. Bernabei R, Landi F, Bonini S, Onder G, Lambiase A, Pola R, Aloe L: Effect of topical application of nerve-growth factor on pressure ulcers. Lancet 1999, 354:307.

157. Landi F, Aloe L, Russo A, Cesari M, Onder G, Bonini S, Carbonin PU, Bernabei $\mathrm{R}$ : Topical treatment of pressure ulcers with nerve growth factor: $a$ randomized clinical trial. Ann Intern Med 2003, 139:635-641.

158. Chiaretti A, Piastra M, Caresta E, Nanni L, Aloe L: Improving ischaemic skin revascularisation by nerve growth factor in a child with crush syndrome. Arch Dis Child 2002, 87:446-448

159. Calza L, Giardino L, Giuliani A, Aloe L, Levi-Montalcini R: Nerve growth factor control of neuronal expression of angiogenetic and vasoactive factors. Proc Natl Acad Sci USA 2001, 98:4160-4165.

160. Romon R, Adriaenssens E, Lagadec C, Germain E, Hondermarck H, Le Bourhis $X$ : Nerve growth factor promotes breast cancer angiogenesis by activating multiple pathways. Mol Cancer 2010, 9:157.

161. Tapia V, Gabler F, Munoz M, Yazigi R, Paredes A, Selman A, Vega M, Romero $C$ : Tyrosine kinase $A$ receptor (trkA): a potential marker in epithelial ovarian cancer. Gynecol Oncol 2011, 121:13-23.

162. Lazarovici P, Marcinkiewicz C, Lelkes Pl: Cross talk between the cardiovascular and nervous systems: neurotrophic effects of vascular endothelial growth factor (VEGF) and angiogenic effects of nerve growth factor (NGF)-implications in drug development. Curr Pharm Des 2006, 12:2609-2622.

163. Campos X, Munoz Y, Selman A, Yazigi R, Moyano L, Weinstein-Oppenheimer C, Lara HE, Romero C: Nerve growth factor and its high-affinity receptor trkA participate in the control of vascular endothelial growth factor expression in epithelial ovarian cancer. Gynecol Oncol 2007, 104:168-175

164. Turner JE, Delaney RK: Retinal ganglion cell response to axotomy and nerve growth factor in the regenerating visual system of the newt (Notophthalmus viridescens): an ultrastructural morphometric analysis. Brain Res 1979, 171:197-212.

165. Yip HK, Johnson EM Jr: Retrograde transport of nerve growth factor in lesioned goldfish retinal ganglion cells. J Neurosci 1983, 3:2172-2182.

166. Carmignoto G, Canella R, Candeo P, Comelli MC, Maffei L: Effects of nerve growth factor on neuronal plasticity of the kitten visual cortex. J Physiol 1993, 464:343-360.

167. Carmignoto G, Maffei L, Candeo P, Canella R, Comelli C: Effect of NGF on the survival of rat retinal ganglion cells following optic nerve section. J Neurosci 1989, 9:1263-1272.

168. Lambiase A, Aloe L: Nerve growth factor delays retinal degeneration in C3H mice. Graefes Arch Clin Exp Ophthalmol 1996, 234(Suppl 1):S96-S100.

169. Lenzi L, Coassin M, Lambiase A, Bonini S, Amendola T, Aloe L: Effect of exogenous administration of nerve growth factor in the retina of rats with inherited retinitis pigmentosa. Vision Res 2005, 45:1491-1500.

170. Lambiase A, Centofanti M, Micera A, Manni GL, Mattei E, De Gregorio A, de Feo G, Bucci MG, Aloe L: Nerve growth factor (NGF) reduces and NGF antibody exacerbates retinal damage induced in rabbit by experimental ocular hypertension. Graefes Arch Clin Exp Ophthalmol 1997, 235:780-785.

171. Lambiase A, Bonini S, Micera A, Rama P, Bonini S, Aloe L: Expression of nerve growth factor receptors on the ocular surface in healthy subjects and during manifestation of inflammatory diseases. Invest Ophthalmol Vis Sci 1998, 39:1272-1275.

172. Lambiase A, Rama P, Bonini S, Caprioglio G, Aloe L: Topical treatment with nerve growth factor for corneal neurotrophic ulcers. $N$ Engl J Med 1998, 338:1174-1180.

173. de Castro F, Silos-Santiago I, Lopez de Armentia M, Barbacid M, Belmonte C: Corneal innervation and sensitivity to noxious stimuli in trkA knockout mice. Eur J Neurosci 1998, 10:146-152. 
174. Ebendal T, Persson H: Detection of nerve growth factor mRNA in the developing chicken embryo. Development 1988, 102:101-106.

175. Terenghi G, Zhang SQ, Unger WG, Polak JM: Morphological changes of sensory CGRP-immunoreactive and sympathetic nerves in peripheral tissues following chronic denervation. Histochemistry 1986, 86:89-95.

176. Bonini S, Lambiase A, Rama P, Caprioglio G, Aloe L: Topical treatment with nerve growth factor for neurotrophic keratitis. Ophthalmology 2000, 107:1347-1351. discussion 1351-1342.

177. Lambiase A, Coassin M, Sposato V, Micera A, Sacchetti M, Bonini S, Aloe L: NGF topical application in patients with corneal ulcer does not generate circulating NGF antibodies. Pharmacol Res 2007, 56:65-69.

178. Lambiase A, Aloe L, Centofanti M, Parisi V, Mantelli F, Colafrancesco V, Manni GL, Bucci MG, Bonini S, Levi-Montalcini R: Experimental and clinical evidence of neuroprotection by nerve growth factor eye drops: Implications for glaucoma. Proc Natl Acad Sci USA 2009, 106:13469-13474.

179. Lambiase A, Coassin M, Tirassa P, Mantelli F, Aloe L: Nerve growth factor eye drops improve visual acuity and electrofunctional activity in age-related macular degeneration: a case report. Ann Ist Super Sanita 2009, 45:439-442.

180. Blesch A, Tuszynski M: Ex vivo gene therapy for Alzheimer's disease and spinal cord injury. Clin Neurosci 1995, 3:268-274.

181. Tuszynski MH, Roberts J, Senut MC, U HS, Gage FH: Gene therapy in the adult primate brain: intraparenchymal grafts of cells genetically modified to produce nerve growth factor prevent cholinergic neuronal degeneration. Gene Ther 1996, 3:305-314.

182. Tuszynski MH, Thal L, Pay M, Salmon DP, U HS, Bakay R, Patel P, Blesch A, Vahlsing $\mathrm{HL}, \mathrm{Ho} \mathrm{G}$, et al: A phase 1 clinical trial of nerve growth factor gene therapy for Alzheimer disease. Nat Med 2005, 11:551-555.

183. Mandel RJ: CERE-110, an adeno-associated virus-based gene delivery vector expressing human nerve growth factor for the treatment of Alzheimer's disease. Curr Opin Mol Ther 2010, 12:240-247.

184. CERE-110 in Subjects With Mild to Moderate Alzheimer's Disease. http://clinicaltrials.gov/ct2/show/NCT00087789.

185. Randomized, Controlled Study Evaluating CERE-110 in Subjects With Mild to Moderate Alzheimer's Disease. http://clinicaltrials.gov/ct2/show/NCT00876863.

186. Encapsulated Cell Biodelivery of Nerve Growth Factor to Alzheimerrs Disease Patients (NsG0202). http://clinicaltrials.gov/ct2/show/NCT01163825.

187. Wahlberg LU, Lind G, Almqvist PM, Kusk P, Tornoe J, Juliusson B, Soderman M, Sellden E, Seiger A, Eriksdotter-Jonhagen M, Linderoth B: Targeted delivery of nerve growth factor via encapsulated cell biodelivery in Alzheimer disease: a technology platform for restorative neurosurgery. J Neurosurg 2012, 117:340-347.

188. Hoffman D, Breakefield XO, Short MP, Aebischer P: Transplantation of a polymer-encapsulated cell line genetically engineered to release NGF. Exp Neurol 1993, 122:100-106.

189. Hoffman D, Wahlberg L, Aebischer P: NGF released from a polymer matrix prevents loss of ChAT expression in basal forebrain neurons following a fimbria-fornix lesion. Exp Neurol 1990, 110:39-44.

190. Eriksdotter-Jonhagen M, Linderoth B, Lind G, Aladellie L, Almkvist O, Andreasen N, Blennow K, Bogdanovic N, Jelic V, Kadir A, et al: Encapsulated cell biodelivery of nerve growth factor to the Basal forebrain in patients with Alzheimer's disease. Dement Geriatr Cogn Disord 2012, 33:18-28.

191. Shemesh E, Rudich A, Harman-Boehm I, Cukierman-Yaffe T: Effect of intranasal insulin on cognitive function: a systematic review. J Clin Endocrinol Metab 2012, 97:366-376.

192. Guastella AJ, MacLeod C: A critical review of the influence of oxytocin nasal spray on social cognition in humans: evidence and future directions. Horm Behav 2012, 61:410-418.

193. Rilling JK, DeMarco AC, Hackett PD, Thompson R, Ditzen B, Patel R, Pagnoni $G$ : Effects of intranasal oxytocin and vasopressin on cooperative behavior and associated brain activity in men. Psychoneuroendocrinology 2012, 37:447-461.

194. Mathison S, Nagilla R, Kompella UB: Nasal route for direct delivery of solutes to the central nervous system: fact or fiction? J Drug Target 1998 5:415-441.

195. Liu XF, Fawcett JR, Thorne RG, Frey WH 2nd: Non-invasive intranasal insulin-like growth factor-I reduces infarct volume and improves neurologic function in rats following middle cerebral artery occlusion. Neurosci Lett 2001, 308:91-94.

196. Illum L: Is nose-to-brain transport of drugs in man a reality? J Pharm Pharmacol 2004, 56:3-17.
197. Cattaneo A, Capsoni S, Paoletti F: Towards non invasive nerve growth factor therapies for Alzheimer's disease. J Alzheimers Dis 2008, 15:255-283.

198. Covaceuszach S, Capsoni S, Ugolini G, Spirito F, Vignone D, Cattaneo A: Development of a non invasive NGF-based therapy for Alzheimer's disease. Curr Alzheimer Res 2009, 6:158-170.

199. Capsoni S, Marinelli S, Ceci M, Vignone D, Amato G, Malerba F, Paoletti F, Meli G, Viegi A, Pavone F, Cattaneo A: Intranasal "painless" human Nerve Growth Factors slows amyloid neurodegeneration and prevents memory deficits in App X PS1 mice. PLoS One 2012, 7:e37555.

200. Capsoni S, Covaceuszach S, Marinelli S, Ceci M, Bernardo A, Minghetti L, Ugolini G, Pavone F, Cattaneo A: Taking pain out of NGF: a "painless" NGF mutant, linked to hereditary sensory autonomic neuropathy type $\mathrm{V}$, with full neurotrophic activity. PLoS One 2011, 6:e17321.

201. Lambiase A, Pagani L, Di Fausto V, Sposato V, Coassin M, Bonini S, Aloe L: Nerve growth factor eye drop administrated on the ocular surface of rodents affects the nucleus basalis and septum: biochemical and structural evidence. Brain Res 2007, 1127:45-51

202. Calza A, Florenzano F, Pellegrini D, Tirassa P: Time-dependent activation of c-fos in limbic brain areas by ocular administration of nerve growth factor in adult rats. J Ocul Pharmacol Ther 2011, 27:209-218.

203. Tirassa P: The nerve growth factor administrated as eye drops activates mature and precursor cells in subventricular zone of adult rats. Arch Ital Biol 2011, 149:205-213

204. Dhuria SV, Hanson LR, Frey WH 2nd: Intranasal delivery to the central nervous system: mechanisms and experimental considerations. J Pharm Sci 2010, 99:1654-1673.

205. Capsoni S, Covaceuszach S, Ugolini G, Spirito F, Vignone D, Stefanini B, Amato G, Cattaneo A: Delivery of NGF to the brain: intranasal versus ocular administration in anti-NGF transgenic mice. J Alzheimers Dis 2009, 16:371-388

206. Falsini B, Chiaretti A, Barone G, Piccardi M, Pierri F, Colosimo C, Lazzareschi I, Ruggiero A, Parisi V, Fadda A, et al: Topical nerve growth factor as a visual rescue strategy in pediatric optic gliomas: a pilot study including electrophysiology. Neurorehabil Neural Repair 2011, 25:512-520.

207. Chiaretti A, Falsini B, Servidei S, Marangoni D, Pierri F, Riccardi R: Nerve growth factor eye drop administration improves visual function in a patient with optic glioma. Neurorehabil Neural Repair 2011, 25:386-390.

doi:10.1186/1479-5876-10-239

Cite this article as: Aloe et al: Nerve growth factor: from the early discoveries to the potential clinical use. Journal of Translational Medicine 2012 10:239

\section{Submit your next manuscript to BioMed Central and take full advantage of:}

- Convenient online submission

- Thorough peer review

- No space constraints or color figure charges

- Immediate publication on acceptance

- Inclusion in PubMed, CAS, Scopus and Google Scholar

- Research which is freely available for redistribution 